\title{
Influence of simulated body fluid (normal and inflammatory) on corrosion resistance
}

\section{of anodized titanium}

Influência do fluido corpóreo simulado (normal e inflamatório) na resistência à corrosão do titânio anodizado

Influencia del fluido corporal simulado (normal e inflamatorio) en la resistencia a la corrosión del

\section{titanio anodizado}

Received: 07/22/2021 | Reviewed: 07/30/2021 | Accept: 08/02/2021 | Published: 08/07/2021

Sandra Raquel Kunst

ORCID: https://orcid.org/0000-0002-8060-3981

Feevale University, Brazil

E-mail: tessaro.sandra@gmail.com

David de Oliveira Cerveira

ORCID: https://orcid.org/0000-0002-6814-345X Feevale University, Brazil

E-mail: davidps.oc@hotmail.com

Jane Zoppas Ferreira

ORCID: https://orcid.org/0000-0002-3137-297X Federal University of Rio Grande do Sul, Brazil

E-mail: jane.zoppas@ufrgs.br

Thaís Francine Graef

ORCID: https://orcid.org/0000-0002-8259-4222

Feevale University, Brazil

E-mail: tfg@ outlook.com

Joseane de Andrade Santana

ORCID: https://orcid.org/0000-0001-8766-5379

Federal University of Sergipe, Brazil

E-mail: joseane.santana89@gmail.com

Carlos Leonardo Pandolfo Carone

ORCID: https://orcid.org/0000-0002-4084-4502

Feevale University, Brazil

E-mail: carloscarone@ feevale.br

Fernando Dal Pont Morisso

ORCID: https://orcid.org/0000-0002-9653-9857

Feevale University, Brazil

E-mail: morisso@feevale.br

Cláudia Trindade Oliveira

ORCID: https://orcid.org/0000-0002-4472-5359 Feevale University, Brazil

E-mail: ctofeevale@gmail.com

\begin{abstract}
Titanium has been widely used as biomaterial, especially in implantables, in which osseointegration and corrosion resistance are needed. Studies have shown that the thickness and roughness of porous titanium oxides are related to the osseointegration. According to the literature, the best anodizing conditions for obtaining nanotubes in titanium

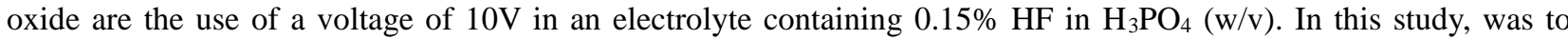
evaluate the corrosion capacity of simulated body fluid (SBF) over titanium samples anodized on 1 mol. $\mathrm{L}-1 \mathrm{H}_{3} \mathrm{PO}_{4}$ and $0.15 \% \mathrm{HF}(\mathrm{w} / \mathrm{v})$ in 1 mol.L-1 $\mathrm{H}_{3} \mathrm{PO}_{4}$. To perform these evaluations samples of commercially pure titanium grade 2 were used. Samples were analyzed by scanning electron microscopy, atomic force microscopy and by electrochemical corrosion tests in healthy and simulating inflammatory conditions. The hydrophobicity of oxides was tested by sessile drop essay, also using SBF. Results show that oxides obtained in $\mathrm{H}_{3} \mathrm{PO}_{4}$ electrolyte, barrier type oxides, work better than the porous oxides obtained in $\mathrm{H}_{3} \mathrm{PO}_{4} / \mathrm{HF}$ electrolyte, suggesting that barrier oxide exhibit more biomaterial characteristics than the porous oxide. These results agree with previous studies, and stand out mainly in relation to the tests performed under inflammatory conditions, more aggressive to the biomaterial.
\end{abstract}

Keywords: Titanium; Dental implants; Corrosion; Body fluids. 


\section{Resumo}

O titânio têm sido amplamente utilizado como biomateriais, principalmente em implantáveis, onde a osseointegração e a resistência à corrosão são necessárias. Estudos têm mostrado que a espessura e a aspereza dos óxidos de titânio porosos estão relacionadas à osseointegração. De acordo com a literatura, as melhores condições de anodização para obtenção de nanotubos em óxido de titânio são a utilização de uma tensão de $10 \mathrm{~V}$ em um eletrólito que contém 0,15\% de $\mathrm{HF}$ em $\mathrm{H}_{3} \mathrm{PO}_{4}(\mathrm{p} / \mathrm{v})$. Neste estudo, o objetivo foi avaliar o desempenho corrosivo no eletrólito de fluido corporal simulado (SBF) em amostras de titânio anodizado de 1 mol.L-1 H ${ }_{3} \mathrm{PO}_{4}$ e 0,15\% de HF (p/v) em 1 mol de L-1 $\mathrm{H}_{3} \mathrm{PO}_{4}$. Amostras de titânio de grau 2 comercialmente puro foram usadas para realizar essas avaliações. As amostras foram analisadas por microscopia eletrônica de varredura, microscopia de força atômica e testes de corrosão eletroquímica em condições inflamatórias simuladas e saudáveis. A hidrofobicidade dos óxidos foi testada pelo teste de gota séssil, também utilizando SBF. Os resultados mostram que os óxidos obtidos no eletrólito de $\mathrm{H}_{3} \mathrm{PO}_{4}$, óxidos do tipo barreira, apresentam melhor desempenho do que os óxidos porosos obtidos no eletrólito de $\mathrm{H}_{3} \mathrm{PO} / \mathrm{HF}_{4} \mathrm{O}$ óxido barreira apresentam mais características de biomaterial que o óxido poroso. Esses resultados são consistentes com estudos anteriores, e se destacam principalmente em relação aos testes realizados em condições inflamatórias, mais agressivas ao biomaterial.

Palavras-chave: Titânio; Implantes dentários; Corrosão; Fluido corporal.

\section{Resumen}

El titanio se ha utilizado ampliamente como biomateriales, especialmente en implantables, en los que se necesita osteointegración y resistencia a la corrosión. Los estudios han demostrado que el grosor y la rugosidad de los óxidos de titanio porosos están relacionados con la osteointegración. Según la literatura, las mejores condiciones de anodización para la obtención de nanotubos en óxido de titanio son el uso de un voltaje de $10 \mathrm{~V}$ en un electrolito que contiene $0.15 \%$ de $\mathrm{HF}$ en $\mathrm{H}_{3} \mathrm{PO}_{4}(\mathrm{p} / \mathrm{v})$. En este estudio, fue para evaluar la capacidad de corrosión del fluido corporal simulado (SBF) sobre muestras de titanio anodizadas en 1 mol. L-1 $\mathrm{H}_{3} \mathrm{PO}_{4}$ y $0.15 \% \mathrm{HF}(\mathrm{p} / \mathrm{v})$ en 1 mol de L-1 $\mathrm{H}_{3} \mathrm{PO}_{4}$. Para realizar estas evaluaciones se utilizaron muestras de titanio grado 2 comercialmente puro. Las muestras se analizaron mediante microscopía electrónica de barrido, microscopía de fuerza atómica y pruebas de corrosión electroquímica en condiciones inflamatorias saludables y simuladas. La hidrofobicidad de los óxidos se probó mediante ensayo de gotas sésiles, también usando SBF. Los resultados muestran que los óxidos obtenidos en el electrolito $\mathrm{H}_{3} \mathrm{PO}_{4}$, óxidos tipo barrera, funcionan mejor que los óxidos porosos obtenidos en el electrolito $\mathrm{H}_{3} \mathrm{PO}_{4} / \mathrm{HF}$, utilizando ese óxido barrera exhiben más características biomateriales que el óxido poroso. Estos resultados concuerdan con estudios previos, y destacan principalmente en relación a las pruebas realizadas en condiciones inflamatorias, más agresivas al biomaterial.

Palabras clave: Titanio; Implantes dentales; Corrosión; Fluido corporal.

\section{Introduction}

Titanium and its alloys have been widely used in the biomedical area, mainly in orthopedic and dental implants and / or prostheses, due to their characteristics of biomaterial (Dubruel et al., 2006; Kang et al., 2010; Park et al., 2012). Dental implants, for example, have been increasingly studied and developed over the years and with the increase in life expectancy and population growth, oral health is becoming increasingly important. Thereby, world implant market foresees substantial growth for the next years, with an increase of about $6.9 \%$ (compound annual rate), going from an evaluation of US $\$ 3.60$ billion in 2016 to US \$ 6.4 billion by 2025. This growth is related mainly to implants made from titanium and zirconium, which are those most used. This market behavior has driven the development of new techniques that guarantee better quality, performance and acceptance of the implant by the patient's body, resisting for longer periods of time maintaining its efficiency.

In view of the importance of biocompatibility, the implant material must be inert in relation to the body tissues, avoiding any type of reaction and exhibiting excellent resistance to corrosion. In addition, it should present high mechanical strength and low density. This scenery points out the titanium as one of the most used materials for this application. With the help of surface treatments and new improvements of using this material, titanium have been better succeeded in the extension of the implant lifetime (Lütjering et al. 2007; Brånemark et al., 1969). This success is based on the theory that increased bone/implant contact can be achieved by changing topography or by increasing the implant surface roughness (Le Guéhennec, Soueidan, Layrolle, \& Amouriq, 2007). These changes are achieved using techniques such as blasting, acid attack, anodic oxidation, biocompatible material coating, ion implantation techniques and plasma vapor deposition techniques, among others. 
Some of these techniques are currently used in implants sold on the world market and, among them, anodic oxidation is one of the most common and flexible method used to modify nanoscale metal surfaces. Anodic oxidation has been used successfully to transform metallic surfaces into nanotubular structures with diameters less than $100 \mathrm{~nm}$. In addition, with a simple adjustment of process parameters, such as the electrolyte composition or applied current density and potential, it seems that the chemical and topographic properties of the surface can be precisely modulated, allowing complete control of its characteristics (Variola et al., 2011).

Literature shows that titanium plates anodized in $\mathrm{H}_{3} \mathrm{PO}_{4} / \mathrm{HF}$ electrolytes present nanotubes with an average diameter of around $70 \mathrm{~nm}$. This diameter is considered adequate for osseointegration, whose average pore spacing must place between $15 \mathrm{~nm}$ and $30 \mathrm{~nm}$ and for a surface containing tubes, this distance should not exceed $70 \mathrm{~nm}$ (Park et al., 2007; Kunst et al., 2020).

However, the corrosion resistance of titanium, despite its high resistivity, is compromised by the immersion of the metal in biological fluids (Almeida, 2018). In order to artificially simulate the conditions existing inside the human body, cnsidering perform laboratory analisys, the simulated body fluid (SBF) has been widely used. Various compositions of SBF have been studied, due to the natural variations that can occur in the human body (such as infections, fever, or some disease), modifying the environment in which the biomaterial is inserted, and consequently its performance (Bohner, 2009; Kokubo et al., 1990).

Thus, the present work aims to anodize samples of comercially purep titanium (titanium cp) plates used in the manufacture of biomaterials in two different conditions: aqueous solution of 1 mol.L-1 $\mathrm{H}_{3} \mathrm{PO}_{4}$ and, in aqueous solution of 1 mol.L $\mathrm{L}^{-1} \mathrm{H}_{3} \mathrm{PO}_{4}$ containing $0.15 \% \mathrm{HF}$ (w/v) (Kunst, 2020). Also, it was objetive of this work, to evaluate anodizing process reproducibility, morphologic performance of the anoding samples and the corrosion resistance in healthy simulated body fluid and in simulating inflammatory process.

\section{Methodology}

\section{Chemicals}

For the accomplishment of this work the following reagents, in analytical grade and without any previous treatments, such as sodium chloride ( $\mathrm{NaCl}$ p.a. ACS, Synth, Diadema, Brazil), sodium bicarbonate $\left(\mathrm{NaHCO}_{3}\right.$ p.a. ACS, Synth, Diadema, Brazil), potassium chloride ( $\mathrm{KCl}$ p.a. ACS, Synth, Diadema, Brazil), potassium phosphate dibasic trihydrate $\left(\mathrm{K}_{2} \mathrm{HPO}_{4} \cdot 3 \mathrm{H}_{2} \mathrm{O}\right.$, Merck KGaA, Darmstadt, Germany), magnesium chloride hexahydrate $\left(\mathrm{MgCl}_{2} \cdot 6 \mathrm{H}_{2} \mathrm{O}\right.$, Merck KGaA, Darmstadt, Germany), calcium chloride $\left(\mathrm{CaCl}_{2}\right.$ p.a. ACS, Synth, Diadema, Brazil), sodium sulfate $\left(\mathrm{Na}_{2} \mathrm{SO}_{4}\right.$ p.a. ACS, Synth, Diadema, Brazil), hydrochloric acid ( $\mathrm{HCl} 37 \%$, Química Moderna, Barueri, Brazil), hydrofluoric acid (HF 50\%, Química Moderna, Barueri, Brazil), nitric acid $\left(\mathrm{HNO}_{3} 54 \%\right.$, Química Moderna, Barueri, Brazil) and phosporic acid $\left(\mathrm{H}_{3} \mathrm{PO}_{4} 85 \%\right.$, Neon, Suzano, Brazil) were used.

\section{Titanium plates}

A milled titanium cp grade 2 plate (Titânio Brasil Ltda.), in circular shape with $1 \mathrm{~mm}$ thick and $1.5 \mathrm{~cm}$ in diameter was used in this work. This material meets the chemical composition required by ASTM F67:13 standard for forged alloys used in cirurgical implants and Table 1 describes the material chemical compostion. 
Table 1. Chemical composition of titanium cp grade 2 plates.

\begin{tabular}{cc}
\hline Element & Composition (\%) \\
\hline Nitrogen (maximum) & 0.03 \\
Carbon (maximum) & 0.08 \\
Hydrogen (maximum) & 0.02 \\
Iron (maximum) & 0.30 \\
Oxygen (maximum) & 0.25 \\
Waste (maximum each) & 0.10 \\
Waste (maximum total) & 0.40 \\
Titanium & Balance \\
\hline
\end{tabular}

Source: Authors.

\section{Anodizing process}

Before anodizing process, titanium samples were etched in a $\mathrm{HNO}_{3}: \mathrm{HF}(60 / 40, \mathrm{v} / \mathrm{v})$ solution, for a few seconds, whashed with purified water and dryed, to remove oils, dirt and oxides from the surface, ensuring homogeneity and adhesion of the anodized film, as well as its best efficiency as an anti-corrosion coating.

The anodizing process was performed using $300 \mathrm{~V}-500 \mathrm{~mA}$ voltage source attached to a computer with software for data recording, appliyng a constant potential of $10 \mathrm{~V}$, for 30 minutes, at room temperature. The sample was connected as anode and platinum as cathode. The electrolytes used for anodization were $1 \mathrm{~mol} \mathrm{~L}^{-1}$ aquous solution of $\mathrm{H}_{3} \mathrm{PO}_{4}$ and $1 \mathrm{~mol} \mathrm{~L}^{-1}$ aquous solution of $\mathrm{H}_{3} \mathrm{PO}_{4}$ added of $0.15 \%$ (w/v) $\mathrm{HF}$ (Kunst et al., 2020), to obtain barrier and porous oxides respectivelly.

\section{Electrolyte for electrochemical characterization}

Among the various techniques employed to the study of biomaterials behavior, the use of SBF (simulated body fluid) solution as electrolyte to observation of electrochemical behavior has shown to be very promising for the purpose of simulating the conditions of the body environment (Brooks, 2017). Thus, the SBF electrolyte prepared according the protocol suggested by Kokubo and Takadama (Kokubo et al., 2006) was used to the electrochemical tests. At the end of formulation process, 1 mol L-1 hydrochloric acid solution was used to adjust the $\mathrm{pH}$ value to 7.41 , referring to the healthy body environment and for 5.0 simulating an inflammatory process (Brooks, 2017).

\section{Surface characterization of anodized layer}

The morphological analisys of the anodized layer surfaces was performed by scanning electron microscopic (SEM) on a JSM-6510LV equipment (JEOL, Japan) with $20 \mathrm{keV}$ acceleration voltage. Thickness, by cross section, and the surface of the anodized layer, in top view, were evaluated.

Atomic force microscopy (AFM) images were generated by a Shimadzu SPM-9700 microscope, operating in contact mode, with silicon nitride probes (nanosensors), with $8 \mu \mathrm{m}$ vertical variation and $10 \times 10 \mu \mathrm{m}$ scanning area. The evolution of surface roughness was evaluated by average roughness (Ra) measurements obtained with the aid of the Image J free software.

The surfaces hydrophobicity was determined by contact angle measurement applying the sessile drop method in an equipment OCA 15EC (Dataphysics, Germany) and using $0.4 \mathrm{~mm}$ needle syringe with SBF droplets of about $8 \mu \mathrm{L}$ obtained with flow rate of $2.0 \mu \mathrm{L} \cdot \mathrm{s}^{-1}$. 
All electrochemical analyzes were performed using an Autolab PGSTAT 302 potentiostat (Metrohm, The Netherlands). The measurements were perfromed in SBF electrolite solution at healthy $\mathrm{pH}$ of 7.4 and at inflammatory $\mathrm{pH}$ of 5.0. A cell with three electrodes was used, titanium was the working electrode, platinum was the counter electrode and saturated calomel was the reference electrode. The exposed area for the electrochemical analyzes was $1.76 \mathrm{~cm}^{2} \pm 0.2 \mathrm{~cm}$.

Potentiodynamic polarization was performed with scanning of $1 \mathrm{mV} \cdot \mathrm{s}^{-1}$ between $-200 \mathrm{mV} \mathrm{s} \mathrm{s}^{-1}$ and $+400 \mathrm{mV} \mathrm{s}{ }^{-1}$ with respect to the open circuit potential. The open circuit potential of the samples was monitored during the immersion time of the samples in the SBF solutions without current application. This practice allows to monitor the variation of the corrosion potential, as well as stabilize this potential for the electrochemical impedance spectroscopy assays.

Electrochemical impedance spectroscopy measurements were performed between $100 \mathrm{kHz}$ to $3 \mathrm{mHz}$ with a $20 \mathrm{mV}$ sinusoidal signal. Analyzes were carried out in SBF solutions at healthy $\mathrm{pH}$ of 7.4 and at inflammatory $\mathrm{pH}$ of 5.0 for 384 hours, every 24 hours.

\section{Results and Discussion}

\section{Anodization transients}

Figure 1 shows the current and potential density transients of the anodized samples in $1 \mathrm{~mol} \mathrm{~L}^{-1} \mathrm{H}_{3} \mathrm{PO}_{4}$ without and with the addition of $0.15 \% \mathrm{HF}$, samples covered by a superfical layer of barrier oxide and porous oxide respectively. For better visualization of the phenomena, the graphs were plotted in 1800 seconds and in 4 seconds of anodization. 
Figure 1. Transients of current density ( $\mathrm{a}$ and b) and potential (c and d) of anodized titanium in 1 mol L-1 $\mathrm{H}_{3} \mathrm{PO}_{4}(\mathrm{barrier}$ oxide) and in 1 mol L-1 H3 $\mathrm{PO}_{4}+\mathrm{HF}$ (porous oxide), collected for 1800 seconds (a and c) and in 4 seconds detail (b and d).
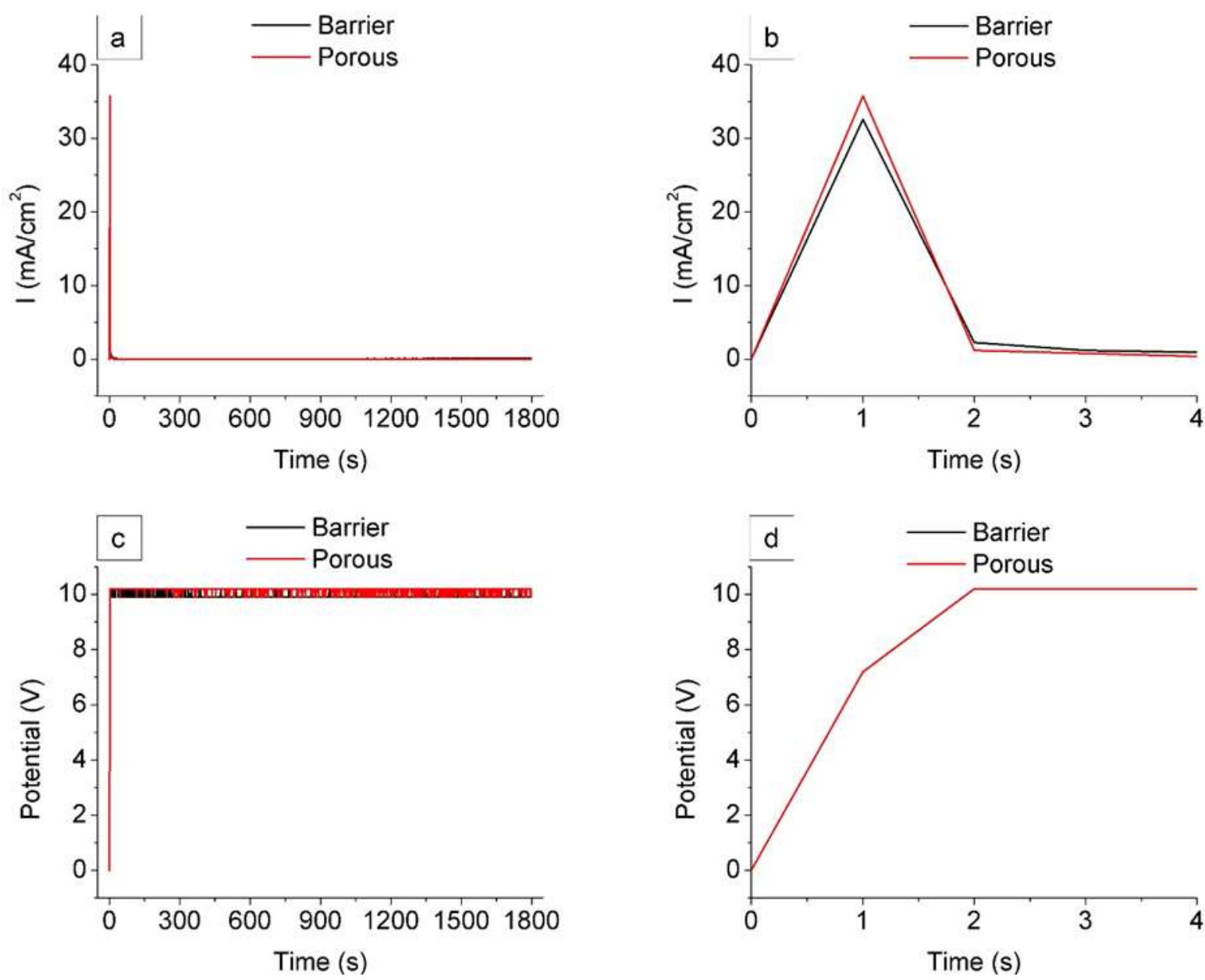

Source: Authors.

Figure 1 ( $b$ and d) shows a signal increasement in the initial seconds for both samples. This response was expected once the first seconds of the process are associated with the starting of the oxide layer formation. The increasement of the potential over the first seconds of the process is related to the thickness of the oxide and the low value of $10 \mathrm{~V}$ indicates the formation of fine oxide (c and d) (C.J.Dell'Oca et al., 1971).

The literature (Brooks, 2017) describes a constant slope for the potential vs. time curve transient of titanium anodized in phosphoric acid and defines this slope as anodization rate. The thickness of the anodic oxide increases linearly with an increase in potential during anodizing. However, the growth constant $\left(\mathrm{nm} \mathrm{V}^{-1}\right)$ in phosphoric acid is practically constant for the studied potentials between 20 to $100 \mathrm{~V}$, while the current efficiency in all other alkaline electrolytes tested decreased. It is worth to note that the behavior described in the literature is similar to that observed in Figure 1, graphs $\mathrm{c}$ and $\mathrm{d}$.

Nevertheless, even with the low current density observed during anodization and the transients behaving in a similarly way in different anodizing electrolytes, the formation of nanotubes in the titanium samples anodized with 1 mol $\mathrm{L}^{-1}$ aquous solution of $\mathrm{H}_{3} \mathrm{PO}_{4}$ added of $0.15 \%$ (w/v) $\mathrm{HF}$, was expected due to the presence of $\mathrm{HF}$ in the electrolyte, causing oxide transition of the barrier type to the porous type. The formation of nanotubes was already observed by Kunst (Kunst et al., 2020), but the anodizing transients showed behavior of barrier oxide formation despite forming nanotubes. Unfortunately, according to the literature (Kowalski, 2013), the formation of some nanostructures such as $\mathrm{TiO}_{2}$ nanotubes, are more complex 
in view of their growth mechanism, the dissolution of oxide and stresses at the metal-oxide interface. However, the first stages of formation of nanotubular or nanoporous layers are similar to the formation of barrier type layers. Thus, the information necessary to model the initial stages of tube growth is often obtained from studies on the growth of barrier type layers.

Currently, in view of the available analytical techniques, some of the kinetic parameters can be obtained from barrier type layers, since their growth and structure are much simpler. An example of this is the fluoride ion present in the anodizing electrolyte, which is essential for the growth of many nanotubular and nanoporous structures. In the barrier type titanium oxide, under specific conditions, the migration rate of fluorides throught the oxide towards the metal is twice as high as that of oxygen ions. The layer plenty of fluoride ions and deficient in oxygen is often found at the base of the oxide (metal/oxide interface), which is soluble in water, causing preferential paths for the formation of nanotubular $\mathrm{TiO}_{2}$ (Kunst et al., 2020).

\section{SEM analysis of non-anodized and anodized samples in $1 \mathrm{~mol} \mathrm{~L}^{-1} \mathrm{H}_{3} \mathrm{PO}_{4}$ without and with addition of $0.15 \% \mathrm{HF}$.}

Figure 2 shows the micrographs obtained by SEM in top view for titanium samples uncovered, covered by barrier oxide and by porous oxide observed at magnitudes of 1000 and 5000x.

Figure 2. SEM micrograph in top view of the titanium samples in the conditions: (a) cp grade 2 (1000x), (b) cp grade 2 (5000x), (c) anodized in 1mol L-1 $\mathrm{H}_{3} \mathrm{PO}_{4}$ for 30 min (1000x), (d) anodized in 1 mol L-1 $\mathrm{H}_{3} \mathrm{PO}_{4}$ for 30min (5000x), (e) anodized in 1 mol L-1 $\mathrm{H}_{3} \mathrm{PO}_{4}+0.15 \% \mathrm{HF}$ for $30 \mathrm{~min}(1000 \mathrm{x})$ and (f) anodized in $1 \mathrm{~mol} \mathrm{~L}-1 \mathrm{H}_{3} \mathrm{PO}_{4}+0.15 \% \mathrm{HF}$ for 30 min (5000x).

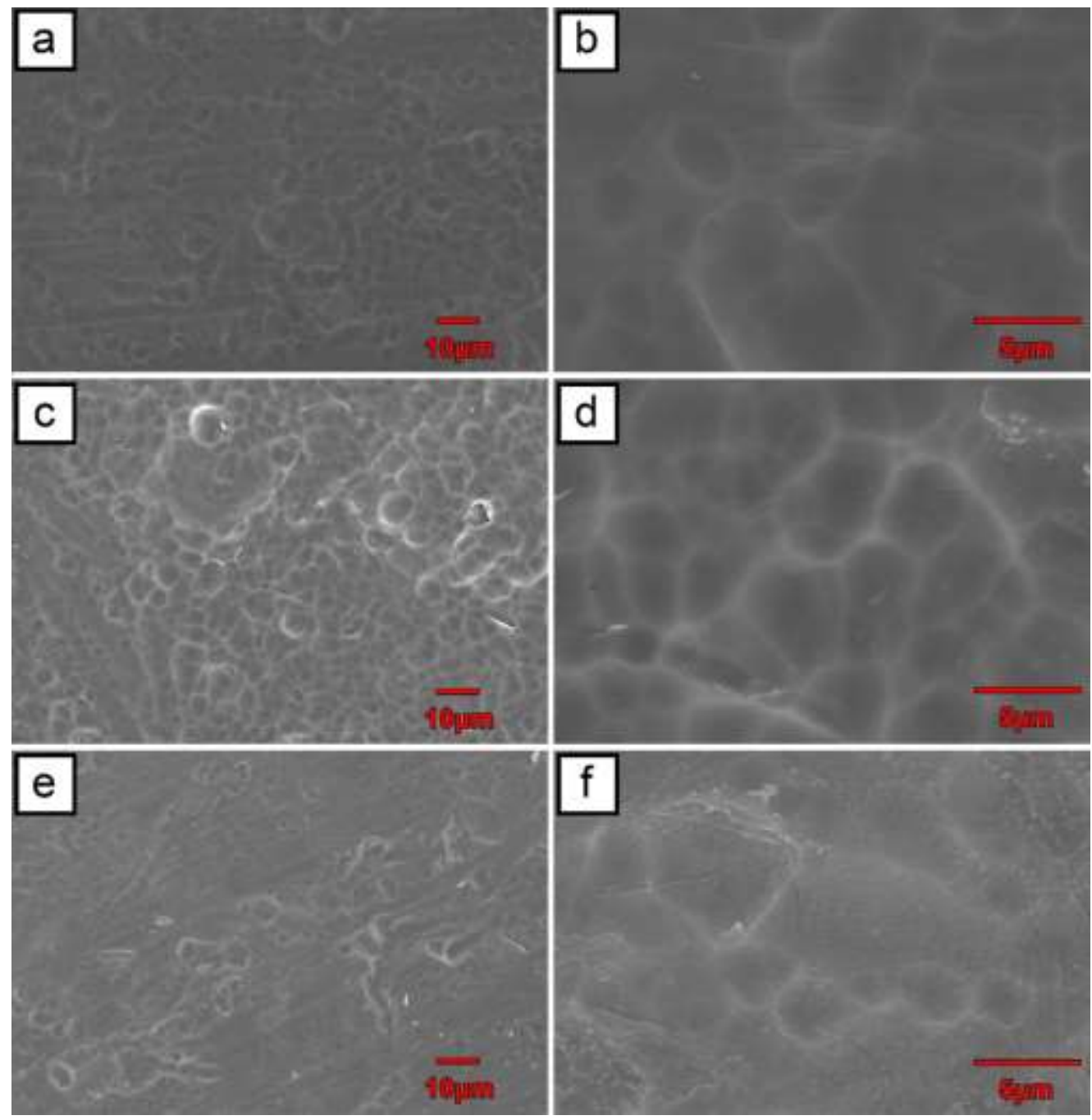

Source: Authors. 
The micrographs of cp grade 2 titanium (Figure 2 a and b) show spherical cavities on the sample surface, which were reported by Oliveira (Oliveira, 2007), and is, probably caused by the pickling with $\mathrm{HNO}_{3}: \mathrm{HF}$. However, as the sample was pickled and dried before being observed by SEM, it can be inferred that there was formation of stable titanium oxide, considering the passive layer of the same oxide that forms naturally on the surface of the metal when in contact with atmospheric oxygen. However, this layer formed in air has low surface hardness and low resistance to wear, especially when applied to joints and/or protheses that suffer constant superficial mechanical stress. Therefore, due to its thin thickness, this layer is not effective enough to protect cp grade 2 titanium when exposed to some aggressive condition (Chen, 2015; Catauro et al., 2014).

The literature (Marino, de Oliviera, Rocha-Filho, \& Biaggio, 2001) describes the oxide grown over titanium surface and the oxide grown over titanium alloy surface, both under atmospheric oxygen, and suggests that the first is more stable than the second. As a consequence, concludes that the alloy elements promote instability to the passive oxide film formed over the metal surface, turning it more vulnerable to corrosion.

The oxidation rate of titanium depends on the medium in which the metal is exposed and can occur in anaerobic condition, where usually water is the oxidizing agent, or in aerobic condition, where the atmospheric oxygen is the oxidizing agent. ${ }^{24}$ When in the human body, titanium naturally develops a dense and passive oxide protective layer which is poorly soluble and poorly reactive at organic media, that is, is inert. This inert and biocompatible oxide layer also protects the metal surface from the ionic dissolution process (Dubruel et al., 2006; J. H. Park et al., 2012; Pentti \& Lundstrom, 1992). Similarly, out of the human body, this oxide layer can be obtained exposing the metal to the atmospheric oxygen. Figures $2 \mathrm{c}$ and $\mathrm{d}$, show a similar morphology for both anodized and non-anodized titanium surfaces when anodization process is carried out in 1 mol $\mathrm{L}^{-1} \mathrm{H}_{3} \mathrm{PO}_{4}$ for 30 minutes, suggesting the formation of a thin barrier oxide film, with a thickness similar to that formed in the atmospheric oxygen.

On the other hand, on the samples anodized in $1 \mathrm{~mol} \mathrm{~L}^{-1} \mathrm{H}_{3} \mathrm{PO}_{4}+0.15 \%$ HF for 30 minutes and shown in Figure $2 \mathrm{e}$ and f, the tubes described by Kunst (Kunst et al., 2020) are not observed. However, is possible to observe small clusters, such as nodules or agglomerates on the metal surface. Based on these observations, is suggested that these agglomerates are formed after the grown of the thin barrier oxide layer, which thickness is determined by the applied potential (Raja, 2005).

In fact, according to the literature (Xing et al., 2013; Liu et al., 2014) these agglomerates are small nuclei of crystalline oxide, mainly formed by the evolution of oxygen. In addition, is also suggested a relationship between anodizing time, increased potential and the formation of flower like structures, that would indicate thickening and aging of the oxide film (Fadl-allah \& Mohsen, 2010; Vermesse et al., 2013).

Thus, a proposal is that initially films of amorphous suboxides and hydroxides may be formed over the titanium surface (Fadl-allah \& Mohsen, 2010) until around of 600 seconds. After that, suboxides and hydroxides may evolve to oxides whit a more complex crystalline structure. To confirm this suggestion is the appearance of the characteristic peaks around 1800 seconds, as was observed in this study.

In this context, as our anodization process was developed in constant potential in the potentiostatic mode, with small current density, the amorphous to crystalline state transition seems to occur in a kind of equilibrium state, with slow changes, differently from what occurs in galvanostatic mode. In this way, the literature (Xing et al., 2013; Fadl-allah \& Mohsen, 2010) reports the obtainment of a film with a large number of clusters of flower like structures, during the anodization in $\mathrm{H}_{2} \mathrm{SO}_{4}$, operating in potentiostatic mode with $30 \mathrm{~V}$, from 30 minutes.

Considering cracks in the oxide layer acting as a dielectric, it is suggested that the formation of the crystalline phase is associated to these cracks' formation. However, the formation of these cracks could be related with the sharp drops in the 
potential transient curve, which was not observed in this study (Figure 1). In this sense the literature (Liu et al., 2014) suggests that amorphous to crystalline phase transition with the oxygen evolution reaction (OER) once the initial amorphous oxide easily may be able to develop electronic conduction.

The generation of oxygen bubbles at the oxide / electrolyte interface creates small pores that reduce the area of electronic conduction, inducing the formed film to undergo modifications for the maintenance of electronic transport and to continue characteristics of the electric field formed in the system (Science, Britain, Science, \& Ng, 1988). These modifications are precisely the arrangement of the oxide atoms in an organized way resulting in crystalline planes at the voids filled with oxygen (Fadl-allah \& Mohsen, 2010). Therefore, the rupture of the dielectric occurs superficially, which justifies the absence of an abrupt fall of the generated potential.

\section{Atomic Force Microscopy (AFM) analysis}

Figures 3, 4 and 5 show two-dimensional and three-dimensional images obtained by atomic force microscopy (AFM) for cp grade 2 titanium, titanium anodized in $1 \mathrm{~mol} \mathrm{~L}^{-1} \mathrm{H}_{3} \mathrm{PO}_{4}$ for 30 minutes (barrier) and the titanium anodized in 1 mol $\mathrm{L}^{-1}$ $\mathrm{H}_{3} \mathrm{PO}_{4}+0.15 \% \mathrm{HF}$ for 30 minutes (porous) respectively.

Figure 3. 2D (a) and 3D (b) images obtained by AFM of the cp grade 2 titanium surface.

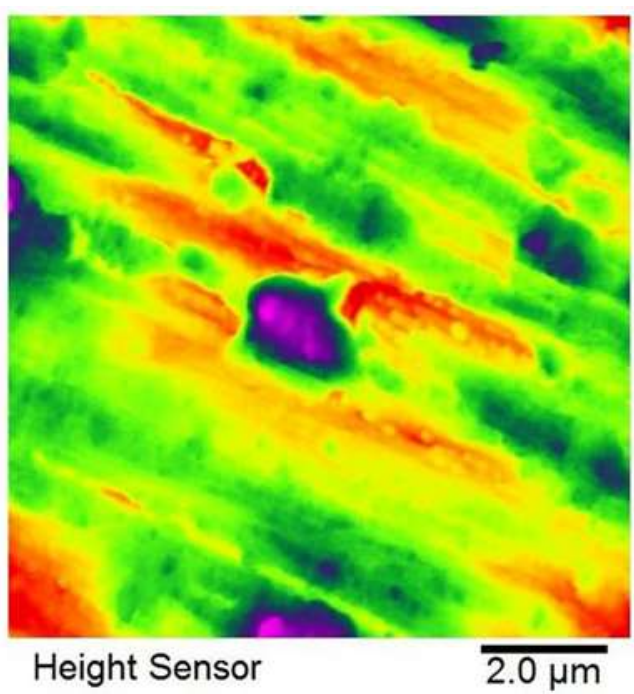

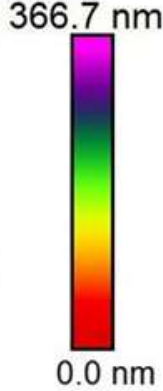

$.0 \mathrm{~nm}$

\section{Height Sensor}

Source: Authors. 
Figure 4. 2D (a) and 3D (b) images obtained by AFM of the titanium surface anodized in 1 mol L-1 H3PO4 for 30 minutes (barrier).
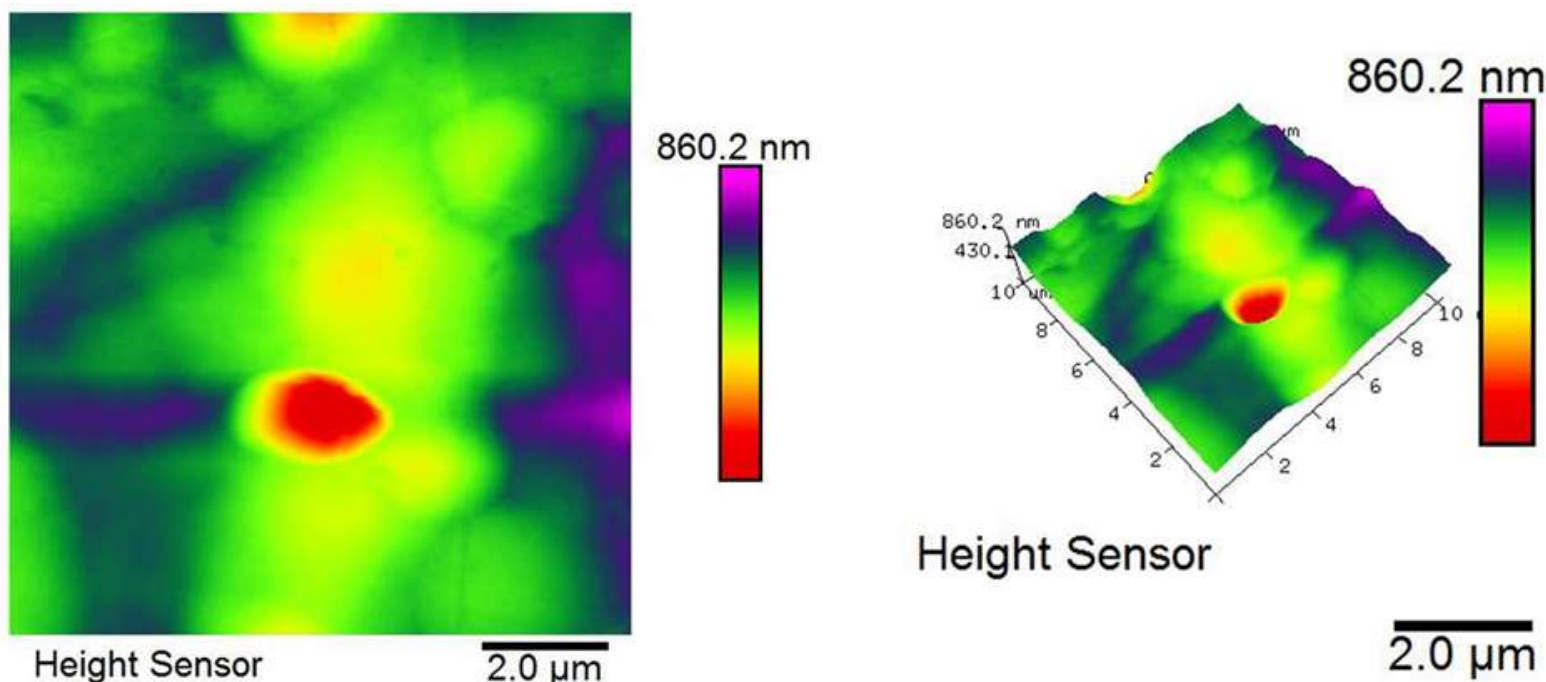

\section{Height Sensor}

Source: Authors.

Figure 5. 2D (a) and 3D (b) images obtained by AFM of the titanium surface anodized in 1 mol $\mathrm{L}^{-1} \mathrm{H}_{3} \mathrm{PO}_{4}+0.15 \% \mathrm{HF}$ for 30 minutes (porous).
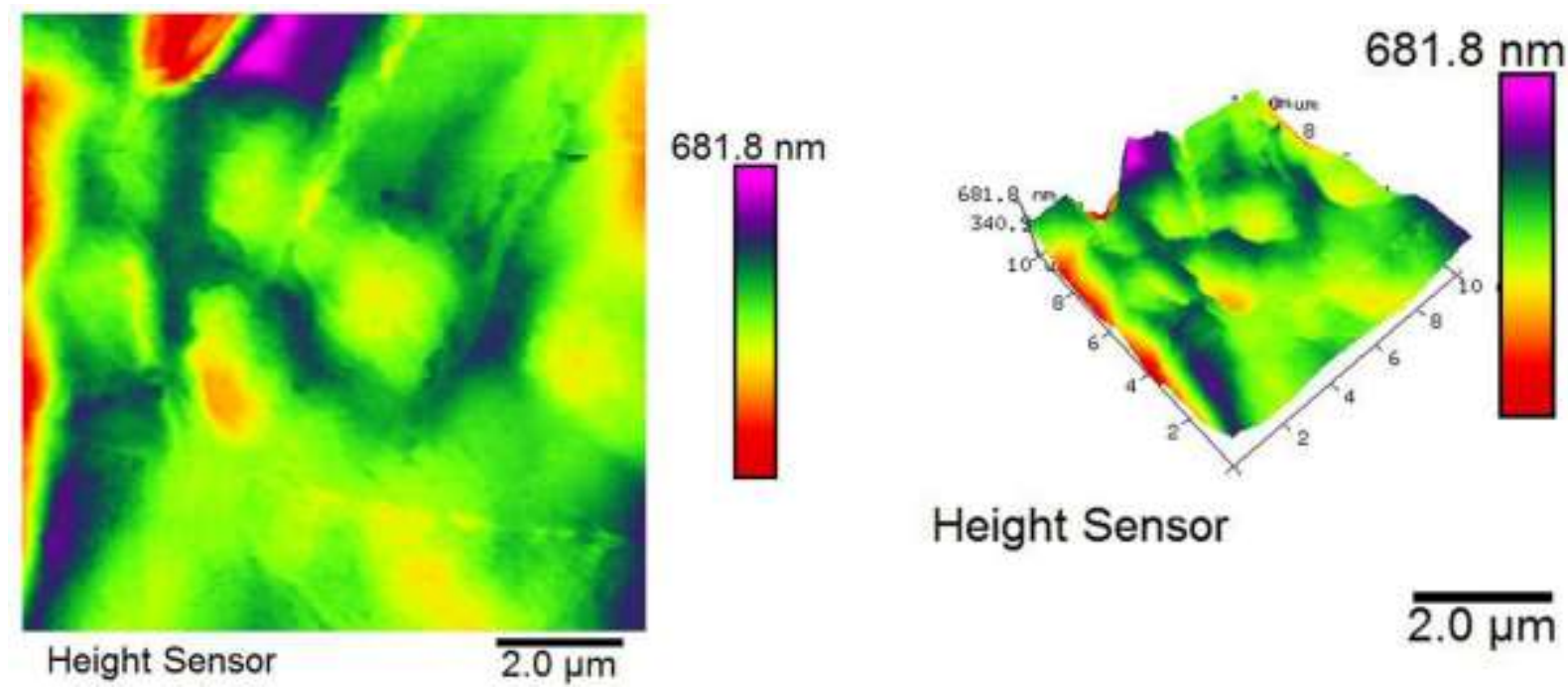

\section{Height Sensor}

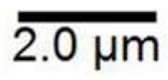


According to the literature (Costa, Sousa, Lucena, Cecilia, \& Souza, 2015) the primary stability of implanted devices with this micro-morphology, even with this magnitude, was confirmed with some success rates of osseointegration, probably due to the increase superficial area due to the thin $\mathrm{TiO}_{2}$ layer. The superficial area is suggested to be the one of the most relevant factors in the process of cell adhesion and differentiation, which helps bone tissue growth and maturation directly on the metal surface and a consequent fast osseointegration.

Figure 4 shows the AFM analysis of the titanium surface cover by a barrier oxide obtained by anodization whit just $\mathrm{H}_{2} \mathrm{PO}_{4}$. It is possible to observe a height difference of $860 \mathrm{~nm}$, larger than the first sample suggesting better biocompatibility (average roughness much closer of $1 \mu \mathrm{m}$ ) (Wieland et al., 2002; Pfeiffer et al., 2003) than cp grade 2.

Application as biomaterial requires a rough surface, once the integration of bone tissue to implants, in vivo, is related to the roughness of the device surface since human osteoblasts adhere better to this type of surface than a smooth one. In this sense, the surface of cp grade 2 titanium, as less rough (Figure 3), should have a smaller contact area and, consequently, osseointegration should be more difficult (Zhou et al., 2018; Yan et al., 2017; Casagrande et al., 2018). At the same time, a good corrosion resistance has been achieved to the sample anodized just in $\mathrm{H}_{3} \mathrm{PO}_{4}$ due to the characteristics of the barrier oxide. But despite the great height difference observed from AFM, could be perceived certain homogeneity of the surface and, at the average, a small roughness which should not interfere in biocompatibility and osseointegration of the implant (Yan et al., 2017).

Figure 5 shows the AFM analysis of the porous sample, anodized in $\mathrm{H}_{3} \mathrm{PO}_{4} / \mathrm{HF}$. This sample exhibit less roughness than the barrier sample, but greater than that of cp grade 2. This rough surface is heterogeneous, and this morphology is associated to the appearance of crystalline structures grown over the oxide surface. In this way, the literature (Ribeiro Filho, Lauro, Bueno, \& Brandão, 2016) has demonstrate that small decreases in the surface roughness can promote a high improvement in resistance to corrosion. Besides the increase of corrosion resistance, the average roughness seems to be enough also to increase the superficial area, favoring the biocompatibility and the osseointegration.

The literature (Zhang, Ge, Men, \& $\mathrm{Li}, 2016$ ) also mention that the electrochemical potential of a metallic implant varies according to the roughness of the surface and a rougher surface presents a lower electrochemical potential. Bearing in mind that the response of cells to implant roughness depends on the cell type (Wen, 2015) the morphological studies are important once some cells have preferences for rough morphologies and others, for smooth ones. These are the cases of osteoblasts or osteoblast-like cells that prefer rough surfaces and the fibroblasts, the most common type of cell found in connective tissue, which have better adhesion to smooth surfaces (Vogler, 1998). Therefore, based on the results of roughness, the anodized samples (barrier and porous) have potential properties of biocompatibility, bioactivity and corrosion resistance to hold both type of cells, better than cp grade 2 .

\section{Wettability analysis (Healthy and Inflammatory)}

The contact angle measurement was performed on cp grade 2, barrier and porous samples using healthy and inflammatory SBF electrolyte. Table 2 shows the contact angle values obtained by the sessile drop method and Figure 6 allows a better comparison between the studied samples. 
Table 2. Values average contact angle obtained by the sessile drop technique.

\begin{tabular}{ccc}
\hline Sample & Average contact angle & Standard deviation \\
\hline Cp grade 2 healthy SBF & 85 & 1.6 \\
Cp grade 2 inflammatory SBF & 78 & 3.1 \\
Healthy SBF barrier & 69 & 3.7 \\
Inflammatory SBF barrier & 31 & 3.2 \\
Porous healthy SBF & 94 & 1.3 \\
Porous inflammatory SBF & 94 & 3.9 \\
\hline
\end{tabular}

Source: Authors.

Figure 6. Graph of contact angle of the analyzed samples.

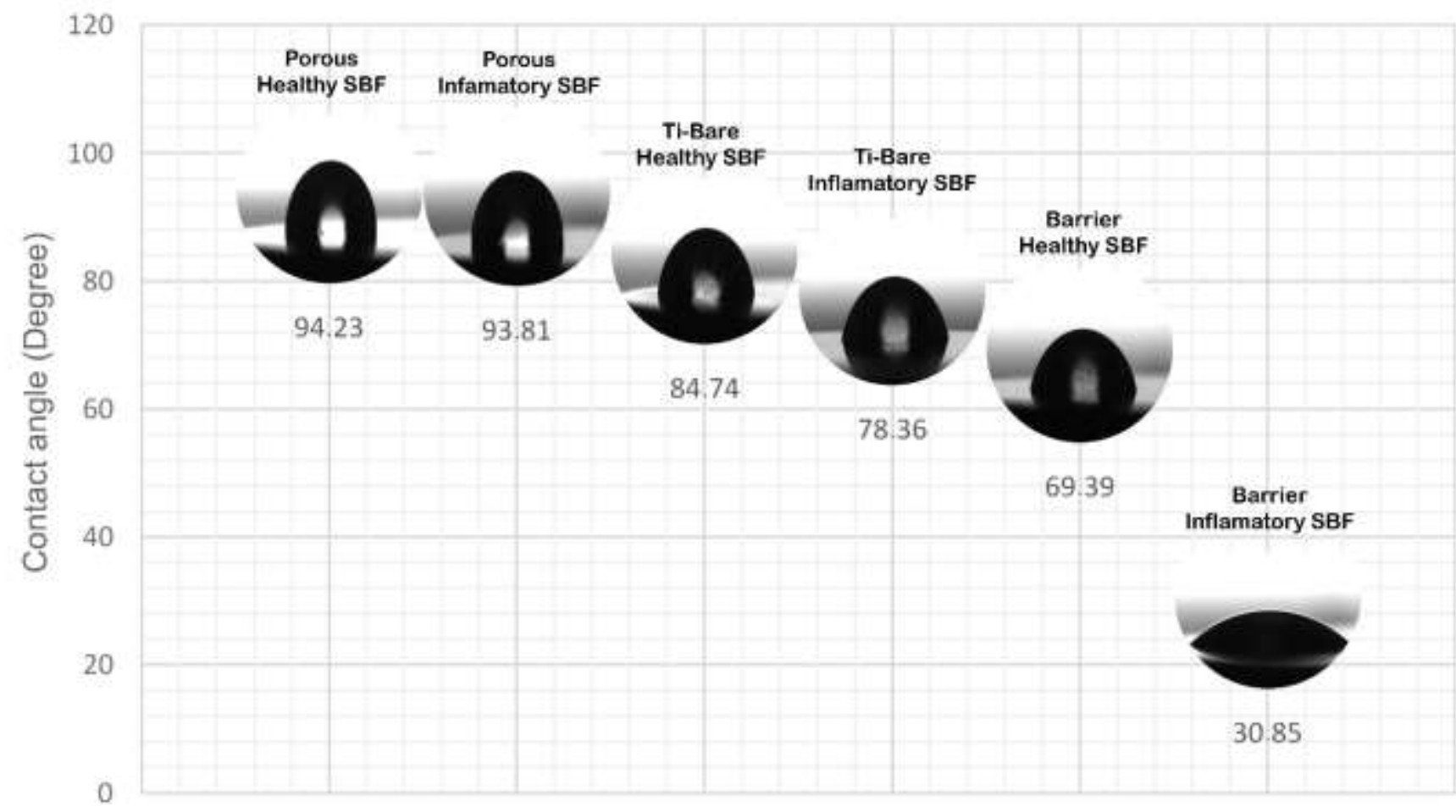

Source: Authors.

As the greater contact angle, greater the hydrophobicity of a surface and angles greater than 70 degrees indicate that the surface is hydrophobic for biomaterials (Vogler, 1998). In this context, it is worth to note that as greater hydrophobic character, less will be the influence of the moisture over the metal surface on an eventual corrosive process. Figure 6 shows the behavior observed for the three samples analyzed in this work.

Analyzing on Figure 6 the cp grade 2 samples, it is observed a hydrophobic character expressed by the measured angles greater than $70^{\circ}$. This hydrophobic character is a consequence of the action of atmospheric oxygen over titanium surface generating a thin layer of oxide which promotes a decrease in free surface energy (Casagrande et al., 2018; Salvador et al., 2018). Studies demonstrate that during the $\mathrm{TiO}_{2}$ growth process, the faces with less formation energy are rather exposed causing decreasing of total free surface energy making them more stable (Albuquerque, Santos, \& Sambrano, 2014). However, 
the inflammatory electrolyte promoted an increase of surface free energy which may be associated with the acid attack of the medium on the oxide resulting in a decrease in the value of the contact angle and making the sample more hydrophilic.

Figure 6 also shows that, on the other hand, barrier sample had the lowest contact angle for both healthy and inflammatory SBF electrolytes. As discussed by the AFM, the barrier sample presented a larger height difference which may have influenced surface behavior to more hydrophilic when compared to the other samples (Zhang et al., 2016; Bruno Serafim Parra, Ronaldo Crosio Gennari \& Boschi, 2006).

However, $\mathrm{pH}$ decrease in the inflammatory electrolyte could be promoting an increase in superficial free energy due to the height difference observed by AFM (Figure 4) of the sample and consequently exhibiting the lowest contact angle value in this study.

The highest values of contact angle obtained for porous sample when compared to cp grade 2 and barrier samples, indicate a more hydrophobic layer, which hinders the permeation of the electrolyte, as well as the leaching of ions into the bodily environment, increasing its anticorrosive performance (Zhang et al., 2016). The SEM micrographs showed small clumps as nodules and therefore promoting an irregular surface, which indicates a greater surface area, which consequently increases the superficial area of the coating with the electrolyte, thus accelerating the corrosion process that begins on the surface (Ribeiro Filho et al., 2016 ;Bruno Serafim Parra, Ronaldo Crosio Gennari \& Boschi, 2006). For this reason, it is believed that the higher values of contact angles obtained for the porous sample are not due to the chemical characteristics of the anodized layer, but to the irregular surface of this sample, which could have influenced the surface energy promoting greater hydrophobicity.

This finding is in accordance with the literature (Ammar et al., 2016; Prządka et al., 2016 ; J. Santana et al., 2020), which states that the surfaces of solids with greater roughness can promote local changes in surface energies, which results in contact angle values different from those measured at an equilibrium condition.

The literature (Shibata \& Tanimoto, 2015) states that hydrophilic surfaces are more desirable than hydrophobic surfaces in view of their better interactions with biological fluids, cells, and tissues. The literature (Goriainov, Cook, M. Latham, G. Dunlop, \& Oreffo, 2014) also highlights that hydrophilic surfaces can absorb proteins more flexibly in vitro, allowing their reorganization by adherent cells, and favoring cell adhesion and dissemination. Therefore, the barrier coating s are favorable since all the other samples studied showed a hydrophobic behavior, with a contact angle greater than $70^{\circ}$.

\section{Potentiodynamic polarization}

The results of the potentiodynamic polarization curves for cp grade 2 and anodized samples are shown in Figure 7, in the two different electrolytes (a) healthy SBF and (b) inflammatory SBF. 
Figure 7. Potentiodynamic polarization curves for $\mathrm{cp}$ grade 2, barrier and porous samples under the influence of electrolyte, (a) healthy and (b) inflammatory.
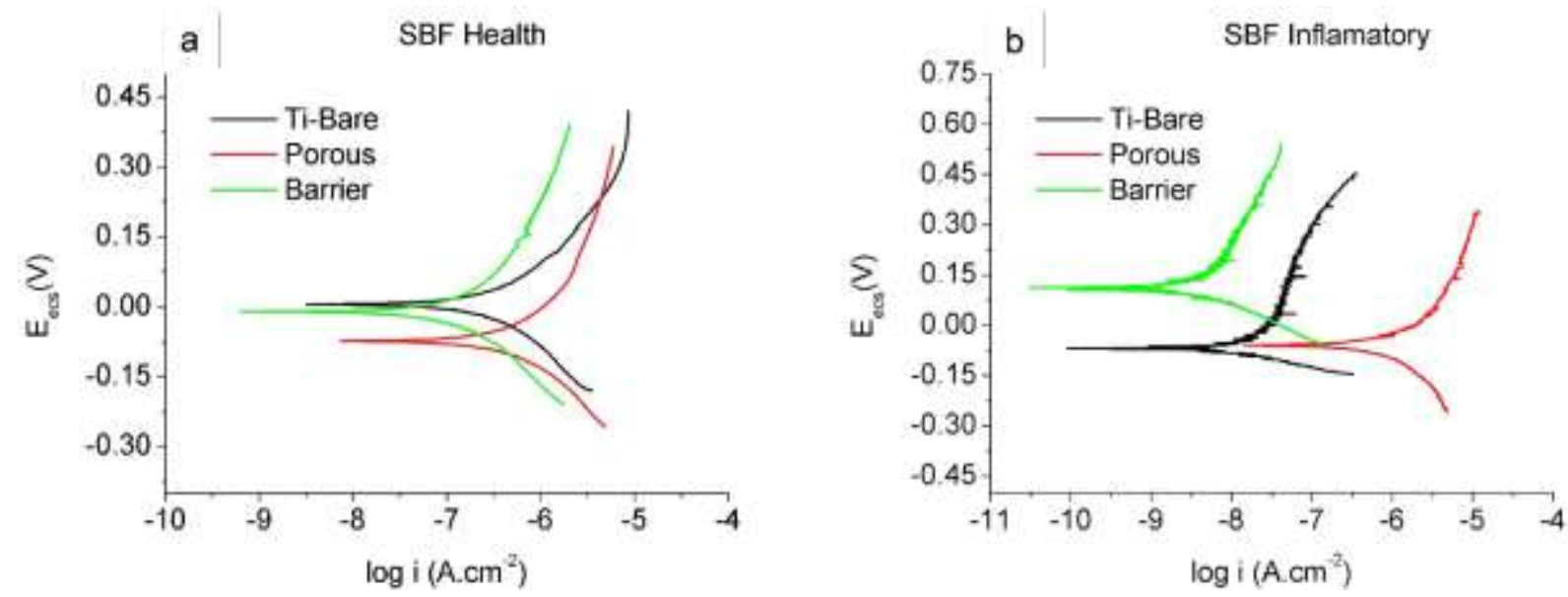

Source: Authors.

The results of the potentiodynamic polarization curves obtained in the healthy electrolyte (Figure 7-a) does not show variation in the corrosion potential for the cp grade 2 and barrier samples. However, this behavior was expected for $\mathrm{cp}$ grade 2 (Figure 7-a), due to the formation of stable passive layer $\mathrm{TiO}_{2}$ naturally formed when in contact with atmospheric. This result corroborates the almost regular morphology presented by SEM (Figure 2) and AFM (Figure 3).

However, porous sample exhibit a small displacement of potential to more active regions. This may occur due to the discontinuities observed by SEM (Figure 2). This sample has small nuclei of crystalline oxide mainly formed by the evolution of oxygen at the oxide/electrolyte interface (Liu et al., 2014; Science et al., 1988). These crystallites are precisely arranged in planes and at localized points (Fadl-allah \& Mohsen, 2010) that creates preferential points of corrosion.

However, cp grade 2 under influence of the inflammatory SBF (Figure 7-b), more corrosive electrolyte whit $\mathrm{pH}=5$, an activation zone is observed, right after the corrosion potential, with subsequent passivation in a potential range of $0.00 \mathrm{~V}$ to close to $0.3 \mathrm{~V}$. From the $0.3 \mathrm{~V}$ potential, there is a slight increase in current density, showing the transpassivation zone. An explanation to this behavior may be the growth of the oxide film followed by a passive dissolution process as illustrated in Figure 8 (Ramires \& Guastaldi, 2002; Dalmau et al., 2013).

Figure 8. Scheme of formation of passive oxide.

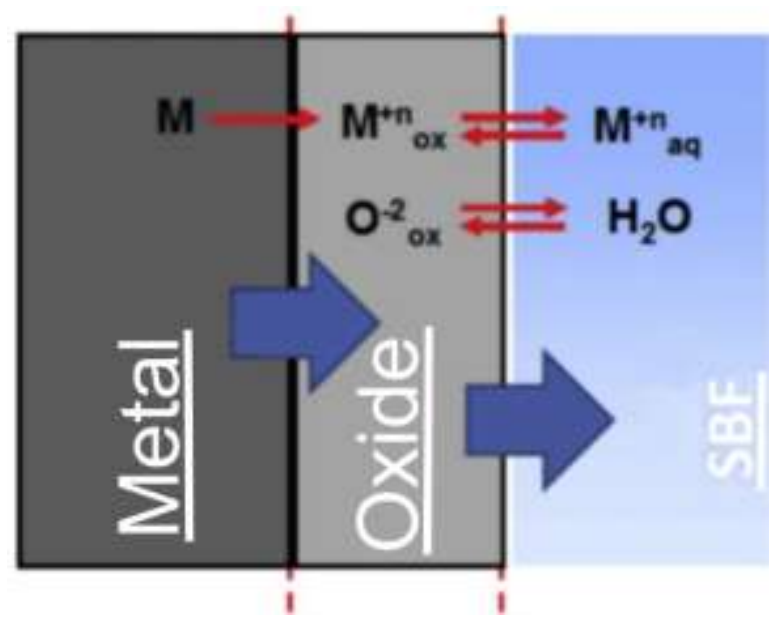

Source: Authors. 
In this way, the damaging process starts with the rupture of the passive layer and with exposure to the biological environment of a point on the implant surface, where the tendency to attack is very high. The damage may obey two types of mechanism, chemical or mechanical. One of the main responsible for the chemical damage of passivity is the chloride ion, abundantly available in body fluids. Mechanical damage occurs when the layer is broken because of tension in the implant or abrasive wear. However, the process of repassivation competes with these mechanisms. Thus, the most common metallic materials for biomedical applications are those whose surfaces, in addition to forming a thin passive film, are capable of selfregenerating at a sufficiently high rate. In the case of $\mathrm{cp}$ grade 2 , self-healing inhibits the exposure of the metal to the medium (Kruger, 1979).

For the barrier sample, there is a lower corrosion density and a shift towards more noble potentials in the inflammatory SBF (Figure 7-b), attesting that this sample allows a longer life to the implants, due to a lower dissolution rate (corrosion). This indicates a better barrier protection for this sample, which consequently decreases the release of metal ions leached from the surface into the medium, which are associated with adverse reactions and cytotoxic effects on the human body (Cremasco et al., 2011).

The porous sample showed the highest corrosion current density in the inflammatory SBF (Figure 7-b), two orders of magnitude greater than sample cp grade 2 and almost three orders of magnitude greater than the barrier sample. According to the morphological characteristics of porous sample, the decrease in $\mathrm{pH}$ has a more aggressive effect. This inappropriate performance for the anodized layer with $1 \mathrm{~mol} \mathrm{~L}^{-1} \mathrm{H}_{3} \mathrm{PO}_{4}+0.15 \% \mathrm{HF}$ for 30 minutes implies bringing several negative results to the patient, among them the fracture of the implant, requiring the insertion of another prosthesis whit its consequences. In the same way, the corrosion product of the implant can cause changes in the histology of the host tissue, both due to direct toxic effects and local hypersensitivity (Araújo \& Couto, 2004).

This information should not be taken as absolute, once biomaterials when implanted in the human body, may be subject to different stresses, making the situation more critical as to corrosion. The corrosion rate determined from the polarization curves are instantaneous measures, that is, they serve to assess generalized corrosion, nothing can be said about time-dependent corrosion processes such as pitting and crevice corrosion, for example.

At the corrosion rate values may vary with the conditions of the human body close to the implant, such as inflammatory processes. The implanted biomaterial may present a difference in the chemical composition and manufacturing process, in relation to the samples that were evaluated. Also, the SBF solution only simulates the body fluid and may differ from the real solution. In addition, each element may have a smaller or greater share in the corrosion current density found in the polarization curves due to its intrinsic resistance to corrosion in the SBF solution (healthy and inflammatory).

\section{SEM micrographs obtained after the Potentiodynamic Polarization Assay}

Figure 9 shows the micrographs obtained by SEM for samples cp grade 2 (a), barrier (b) and porous (c), after potentiodynamic polarization assay in healthy SBF solution. 
Figure 9. SEM micrographs obtained after potentiodynamic polarization in healthy SBF for cp grade 2 (a), barrier (b) and porous (c) samples.
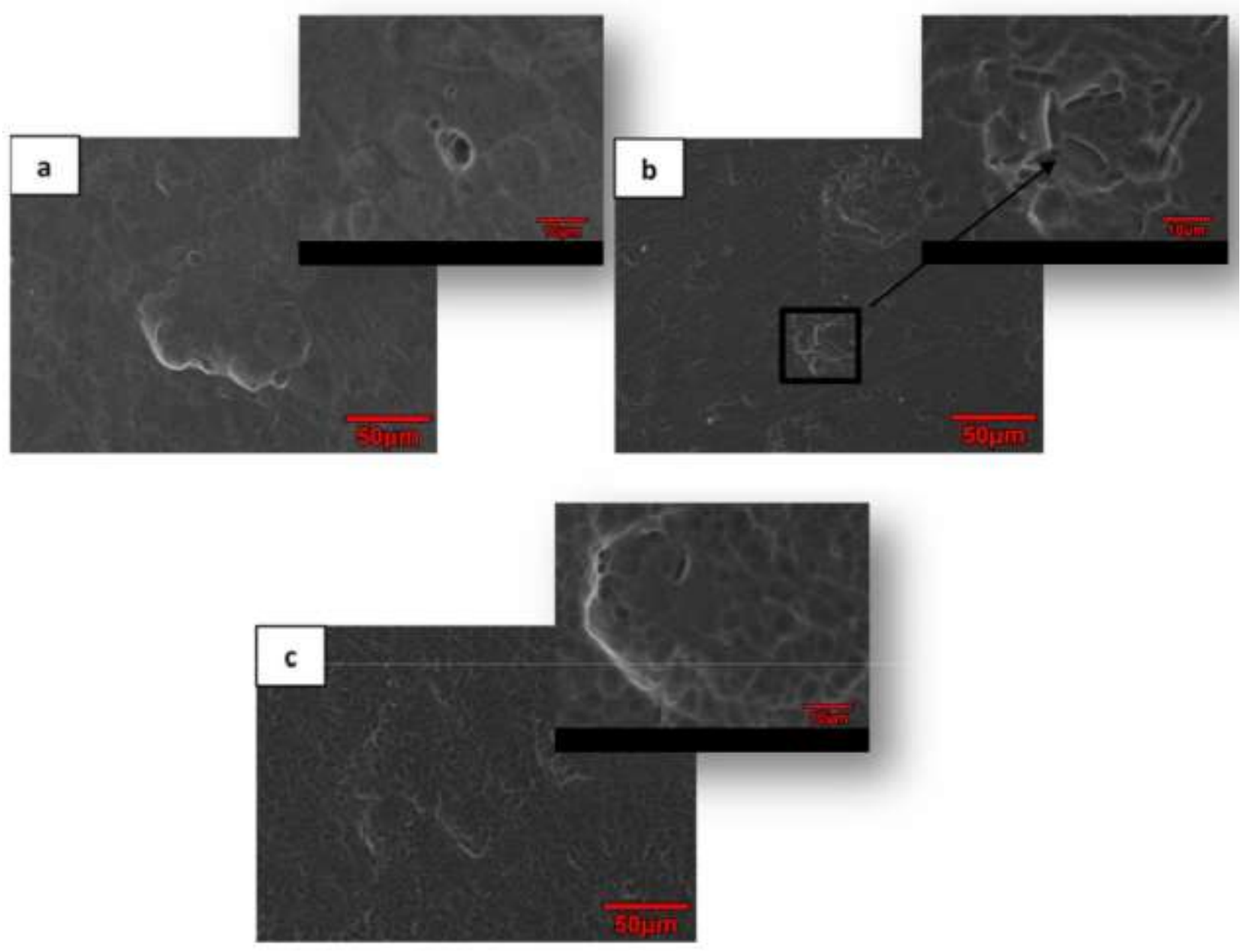

Source: Authors.

Microscopically it was not possible to detect changes in the morphology of the samples, neither the presence of corrosion products or crystals associated with corrosion products, nor changes in the appearance of the samples studied after the polarization tests (Figure 9). There is only a spot corrosion in cp grade 2 due to the fragility of the oxide. These results are in accordance with the polarization curves (Figure 7) in which there was no significant difference regarding the corrosion performance between $\mathrm{cp}$ grade 2 and the other samples, that is, they showed the same order of magnitude of the density of corrosion current, thus maintaining the integrity of the samples when exposed to healthy SBF.

Figure 10 shows the micrographs obtained by SEM for the cp grade 2 (a), barrier (b) and porous (c) samples after a potentiodynamic polarization assay in an inflammatory SBF solution. 
Figure 10. SEM micrographs obtained after potentiodynamic polarization in inflammatory SBF for cp grade 2 (a), barrier (b) and porous (c) samples.
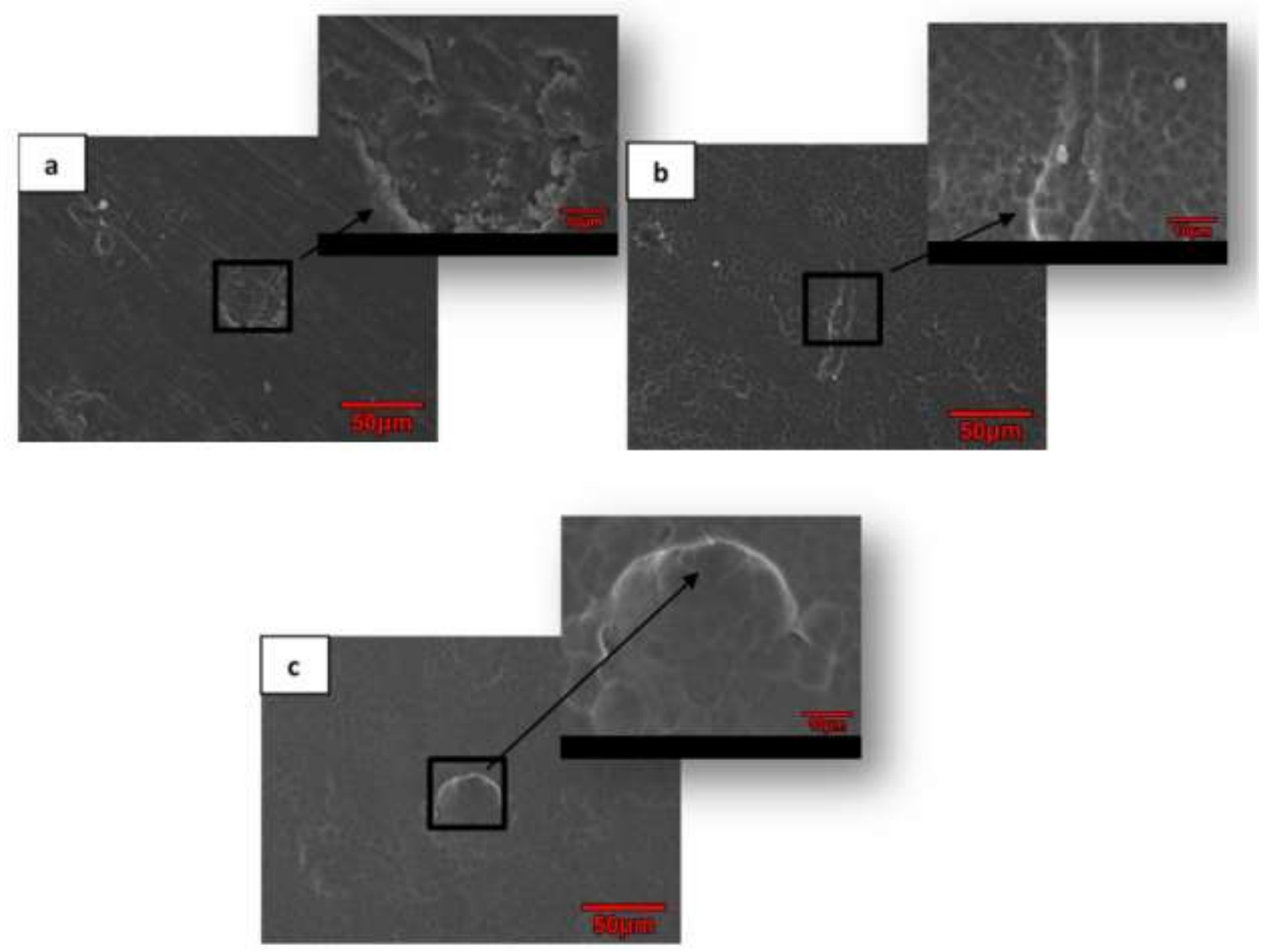

Source: Authors.

In Figure 10, shows that the three samples were more damaged by the inflammatory than by the healthy electrolyte. For sample cp grade 2 (Figure 10-a) is possible to verify greater susceptibility to corrosive attack, probably associated with the process of transpassivation, which causes the formation of $\mathrm{TiO}_{2}$ and $\mathrm{Ti}_{2} \mathrm{O}_{3}$ as well as the dissolution of the passive layer, that is, the deterioration process begins with the rupture of the passive film and with exposure to the biological environment (inflammatory SBF).

For anodized samples, however, more superficial cracks are observed for the barrier sample (Figure 10-b) and deeper for the porous sample (Figure 10-c). It is not possible to say that these cracks are related to the corrosive process, but white spots are can be observed which indicate the probably formation of corrosion products. On the other hand, it should be noted that one of the possible causes of the increase in current density is the heterogeneity of the surface due to the accumulation of crystalline clusters as flower like structures formed on the porous sample. On the other hand, it should be noted that one of the possible causes of the increase in current density is the heterogeneity of the surface due to the accumulation of crystalline clusters as flower like structures formed on the porous sample. This behavior generates an irregular surface, with greater surface area and contact area of coating and electrolyte (inflammatory SBF), accelerating the corrosion process that begins on the surface. These results are in accordance with the corrosive performance in the polarization curves (Figure 7). 


\section{Monitoring of Open Circuit Potential (OCP)}

Figure 11 shows the monitoring of the open circuit potential. This technique was used with the two different electrolytes during 384 hours of immersion for each samples.

Figure 11. Monitoring of open circuit potential for $\mathrm{Cp}$ grade 2, barrier and porous samples under the influence of electrolyte, (a) healthy and (b) inflammatory.
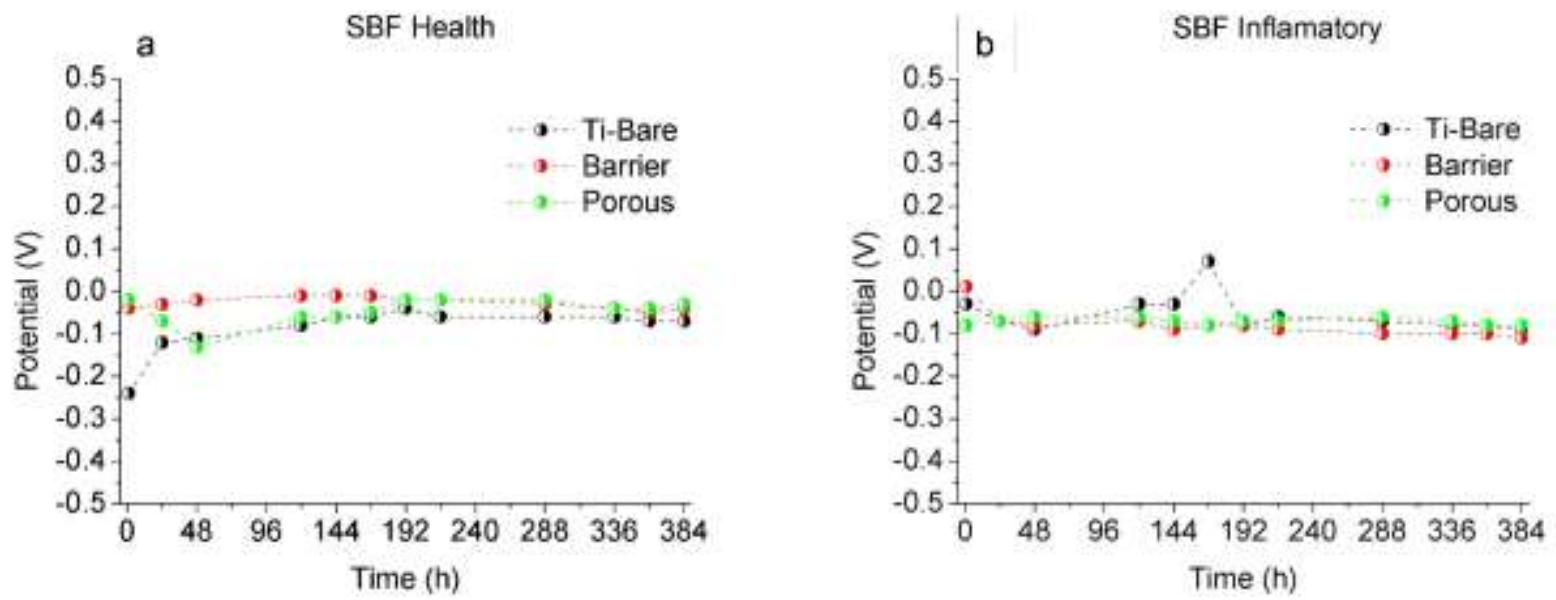

Source: Authors.

The OCP monitoring values (Figure 11) obtained for the barrier, porous samples were very close to the values of the cp grade 2 open circuit potential in the two electrolytes studied. This was already expected, as described in the literature, once the corrosion resistance of titanium is provided by the formation of a stable, adherent and protective passive oxide film which promotes certain stability against corrosive electrolytes (Santana et al., 2020); Salvador et al., 2017). In this way, among the most common oxides of titanium, the most stable is titanium dioxide, spontaneously formed on the metal surface, responsible for the protective characteristic against corrosive processes (Marino et al., 2001).

The oxide layer in physiological media should act in such a way as to prevent direct contact between the tissue and the implant (Kasemo \& Lausmaa, 1985). However, for cp grade 2 it is possible to observe a displacement of the open circuit potential in the direction of more positive potentials during the period of 144 to 192 hours of immersion in the inflammatory electrolyte (Figure 11-b). This performance may be associated with the formation of a less porous passive layer, since it presents a regular surface associated with the formation of stable $\mathrm{TiO}_{2}$ oxide (Figure 3).

Similar values of open circuit potential were also found by other authors in similar works (Souza et al., 2015). However, they claim that high OCP values are temporary, since the oxide stability in the human body is also temporary (Marino et al., 2001; Marino \& Mascaro, 2011) as evidenced whit the oxide dissolution during the immersion time in SBF solution.

These results suggest the wide interaction between the substrate and anodized coating. Thus, it can be said that the changes caused by the anodizing process decreases its susceptibility to corrosion and increasing its bioactivity.

\section{Electrochemical Impedance Spectroscopy (EIS)}

Figure 12 shows the electrochemical impedance spectra obtained during a total time of 384 hours of immersion in healthy SBF and inflammatory SBF solution, expressed as the Bode diagram. 
For cp grade 2, there is only a medium to low frequency phenomenon in healthy SBF at all times of immersion analyzed and up to 120 hours of immersion in inflammatory SBF (Figure 12-a). This behavior reflects the change in electrical conductivity of the passive oxide formed on the surface during exposure to the corrosive medium, possibly related to the charge transfer effect. This oxide response at lower frequencies also testifies to its thermodynamic instability, which justifies that only cp grade 2 did not present a phenomenon displaced from high to medium frequency when compared to barrier (Figure 12-b) and porous (Figure 12- c) denoting the temporary protection provided by oxide (Bojinov et al., 2020; Simons et al., 1999).

Figure 12. Bode diagrams (phase angle) for a total time of 384 hours immersion in healthy SBF and inflammatory SBF solution for the cp grade 2 (a), barrier (b) and porous (c) samples.
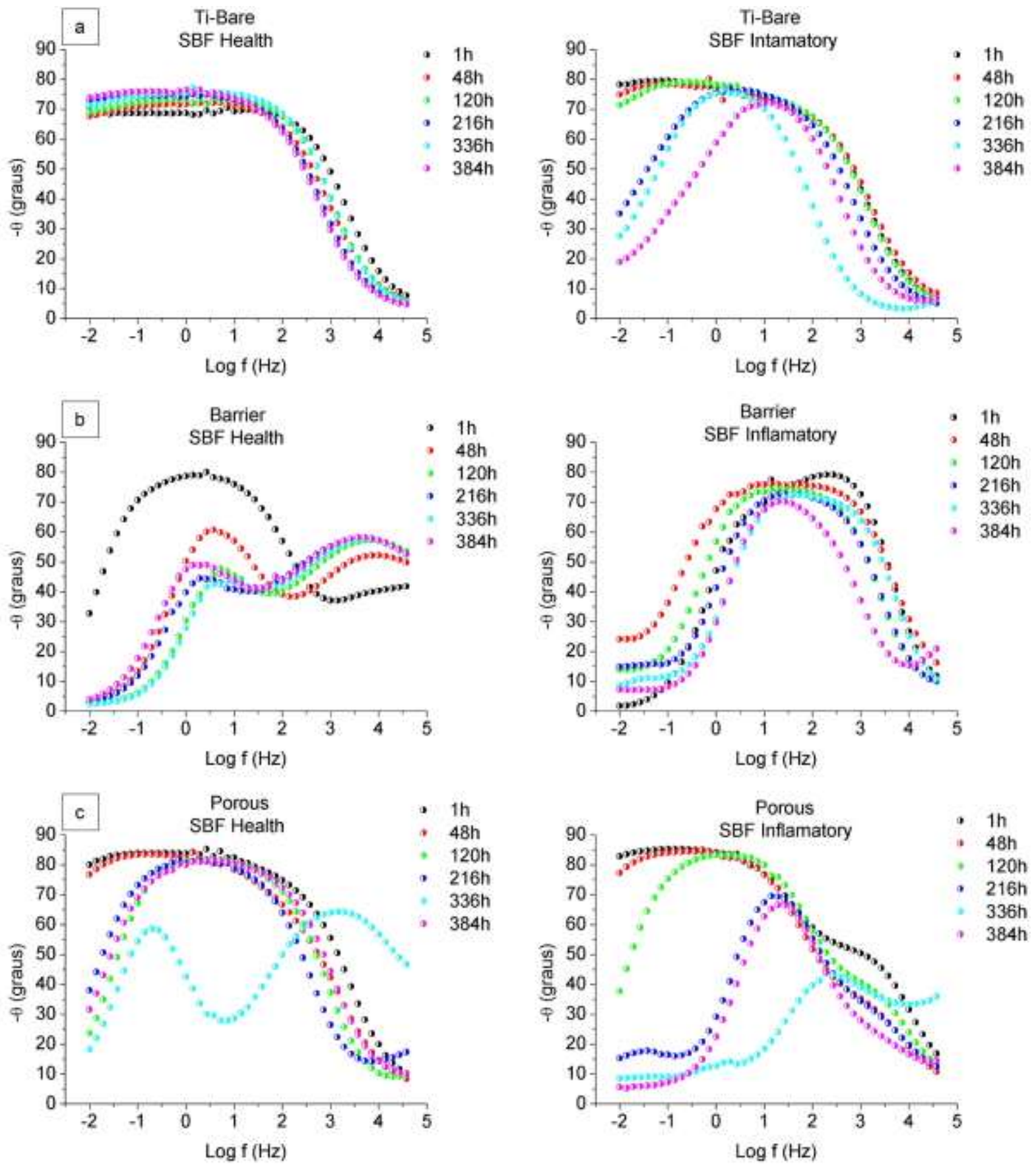

Source: Authors. 
The phase angle for cp grade 2 titanium reached an approximate value of $80^{\circ}$, lower than that reported by the literature(Salvador et al., 2018), that found an angle close to $90^{\circ}$. It was also observed a basically linear variation of the impedance module as a function of the frequency, considering the logarithmic scale, similar to the behavior of an ideal capacitor, until reaching a constant value from higher frequencies, denoting a purely resistive behavior that that can be attributed to the ohmic resistance of the SBF solution.

However, there is a decrease in the phase angle at low frequency for cp grade 2 after 216 hours of immersion in the inflammatory SBF (Figure 12-a). As the inflammatory SBF has an acidic behavior, aggressive ions chemically attack the oxide due to its poor stability, that is, there is a decrease in corrosion resistance and deterioration of the characteristic passivation of cp grade 2. The literature (Salvador et al., 2018) also mentions a decreasing in the phase angle with time of immersion in the EIS tests for titanium and alloys and attributed the presence of this event to the instability of the temporary protection of the oxide formed on the metal surface. In this way (Casagrande et al., 2018), passivation of titanium is not sufficient to ensure adequate corrosion resistance. This behavior agrees with the hydrophilic character presented in this electrolyte observed in the wettability analyzes, Figure 6.

For the barrier sample (Figure 12-b) in the healthy electrolyte, a coupled phenomenon from medium to low frequency is observed, denoting the instability of the film during the first hours of immersion. This instability was observed by other authors during the immersion of protective films in SBF (Kunst et al., 2014). After 48 hours of immersion in healthy SBF, a high frequency phenomenon associated with the anodized layer is observed, which denotes resistance to charge transfer. A medium frequency phenomenon associated with the contribution of the native titanium oxide layer also can be observed (Santana et al., 2020). However, after 120 hours, the phenomenon decreases with the time of immersion due to the permeability of the electrolyte through the anodized layer. This may be associated with the higher roughness value (Figure 4) observed by AFM.

At the end of the test, after 384 hours of immersion, a small increase in the phenomenon is observed in medium frequency associated with corrosion products that temporarily protect the electrolyte coating. These results are in accordance with other work (Cao, Kong, Che, \& Wang, 2017) which observed that the resistance of the corrosive product layer got increased at the end of the test.

The barrier sample when exposed to the inflammatory electrolyte (Figure 12-b), showed only a medium frequency phenomenon denoting the permeability of the electrolyte through the anodized layer, while the high frequency phenomenon disappears suggesting that anodized layer dos not resist to the more aggressive electrolyte with acid $\mathrm{pH}(\mathrm{pH}=5)$. However, this sample exhibits a high angle value until the end of the test, suggesting resistance of the anodized layer. Therefore, the barrier sample seems to show the best performance related to corrosion resistance in the inflammatory SBF electrolyte. This performance implies that this type of oxide can at least minimize or postpone negative effects on the human body, such as possible inflammatory and allergic reactions or even replacements of the implant due to its deterioration. These results are in accordance with the performance of this sample in the polarization curves, in which the lowest corrosion density was found in the inflammatory SBF (Figure 7-b).

Considering the porous sample, a time up to 48 hours of immersion in the healthy electrolyte (Figure 12-c) promotes only a medium to low frequency phenomenon associated with change in electrical conductivity of the passive oxide formed on the surface during exposure in corrosive medium. This phenomenon was also observed for cp grade 2 in the healthy electrolyte, Figure 12-a). This low resistivity in the first hours of immersion may be associated with the fact that this sample has a heterogeneous surface, due to the formation of small nuclei of crystalline oxide (Figure 3). The appearance of crystalline 
phases is associated with the cracking of the oxide surface and the occurrence of preferential paths to the electrolyte with consequent decrease of corrosion resistance (Figure 2).

However, after 120 hours of immersion in the healthy SBF, this phenomenon is observed moving from low to medium frequency and at the end of the test two phenomena arise, one at high frequencies that suggests resistance to charge transfer and other phenomenon at relative low frequencies, associated with the contribution of the native titanium oxide layer at the interface. Like the barrier sample, the generated corrosion products protected the metal surface only temporarily from the electrolyte. Then, the high-frequency phenomenon disappears, and a medium-frequency phenomenon is only observed in 384 hours, associated with the permeability of the electrolyte through the anodized porous layer.

Porous sample, when exposed to the inflammatory electrolyte, behaves similar to when in healthy SBF after 48 hours of immersion, in which a medium to low frequency phenomenon associated with titanium oxide is observed. After 120 hours of immersion, the resistance decreases due to the aggressiveness of the inflammatory electrolyte and in 216 hours a phenomenon appears in medium frequency, associated with the permeability of the electrolyte. Then a phenomenon in low frequency with low angle value after 336 hours of immersion suggests that the corrosion products confer a temporary protection. As a result, the high-frequency phenomenon disappears and only a medium-frequency phenomenon is observed in 384 hours associated with the permeability of the electrolyte through the anodized porous layer with a low angle value (Figure 12-b).

These results corroborate the higher density of corrosion current in the polarization curves of the inflammatory SBF (Figure 7-b), and suggests low resistance of the porous sample, which can cause problems such as inflammatory process, since this scenario causes a drop in pH value in regions close to the implant (Chen \& Thouas, 2015).

Situations like this demonstrate the great importance of the elaboration and characterization of anticorrosive coatings for biomaterials, making it possible to obtain a material capable of developing its specific function with reliability. It is worth mentioning that the implanted biomaterial may present a difference in the chemical composition and manufacturing process, in relation to the samples that were evaluated and that the SBF solution only simulates the body fluid as well as the inflammatory fluid, however it can differ from the real solution.

In this work, we attempt to find a coating that presents a balance between biological and anti-corrosion properties and that has elements that promote biocompatibility and bioactivity without compromising resistance to corrosion.

\section{Micrographs obtained by SEM after EIS}

Figure 13 illustrates the SEM micrographs for the cp grade 2 (a), barrier (b) and porous (c) samples after electrochemical impedance spectroscopy (EIS) assay after 384 hours of immersion in the healthy SBF solution. 
Figure 13. SEM micrographs after EIS (Electrochemical Impedance Spectroscopy) in healthy SBF for cp grade 2 samples (a), barrier (b).
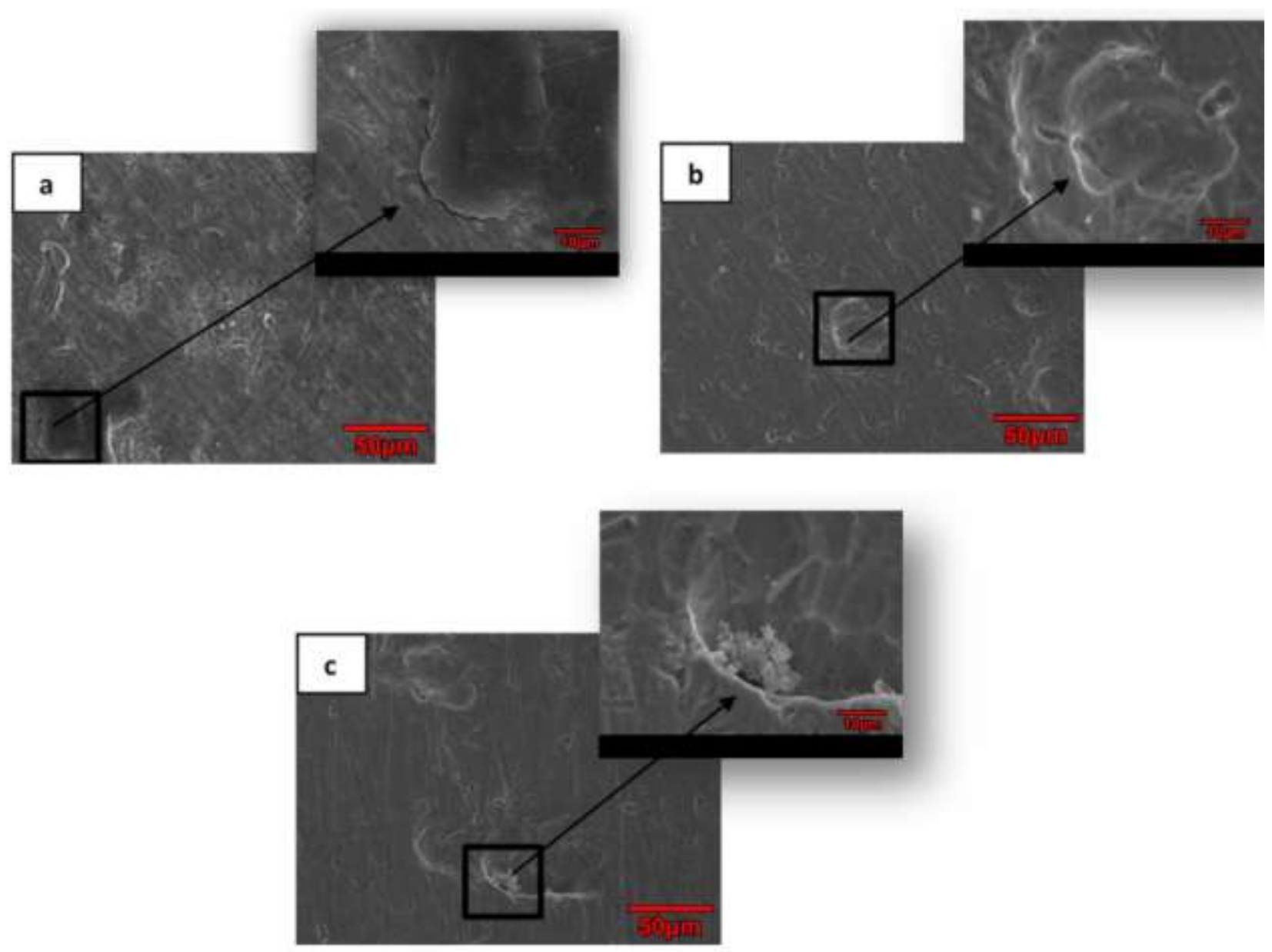

Source: Authors.

Figure 13-a shows that cp grade 2 presents a protective layer associated with the formation of $\mathrm{TiO}_{2}$, which temporarily protects in the healthy SBF solution, however, with cracks after immersion for 384 hours. It suggests, as observed in the Bode diagrams (Figure 12-a), that cp grade 2 sample showed an oxide layer at lower frequencies due to its thermodynamic instability, which justifies that only cp grade 2 did not present a displaced phenomenon of medium to high frequency when compared to the other samples and denotes the temporary protection provided by the oxide.

The barrier sample (Figure 13-b) showed less corrosion products and a more intact layer among the studied samples. These results corroborate the electrochemical impedance spectroscopy analyzes, in which was observed that only this sample had a high frequency phenomenon after 384 hours of immersion in the healthy SBF electrolyte. This performance was associated with corrosion products that temporarily protect oxide layer. Thus, the longer the immersion time, the greater the corrosion resistance. In addition, it is observed that there was a compaction of the layer due to the formation of corrosion products, and consequently this sample showed better resistance to corrosion.

The porous sample (Figure 13-c) showed cracks and imperfections in the anodized layer after the end of the LES test in the healthy SBF (Figure 12-c). This result is consistent with the EIS in which the high frequency phenomenon moves to a medium frequency phenomenon after 384 hours. This shifting can be associated with the permeability of the electrolyte through the anodized porous layer. 
Figure 14 shows the SEM micrographs for cp grade 2 (a), barrier (b) and porous (c) samples after electrochemical impedance spectroscopy (EIS) assay after 384 hours of immersion in the inflammatory SBF solution.

Figure 14. SEM micrographs obtained after EIS (Electrochemical Impedance Spectroscopy) in inflammatory SBF for Cp grade 2 (a), barrier (b) and porous (c) samples.
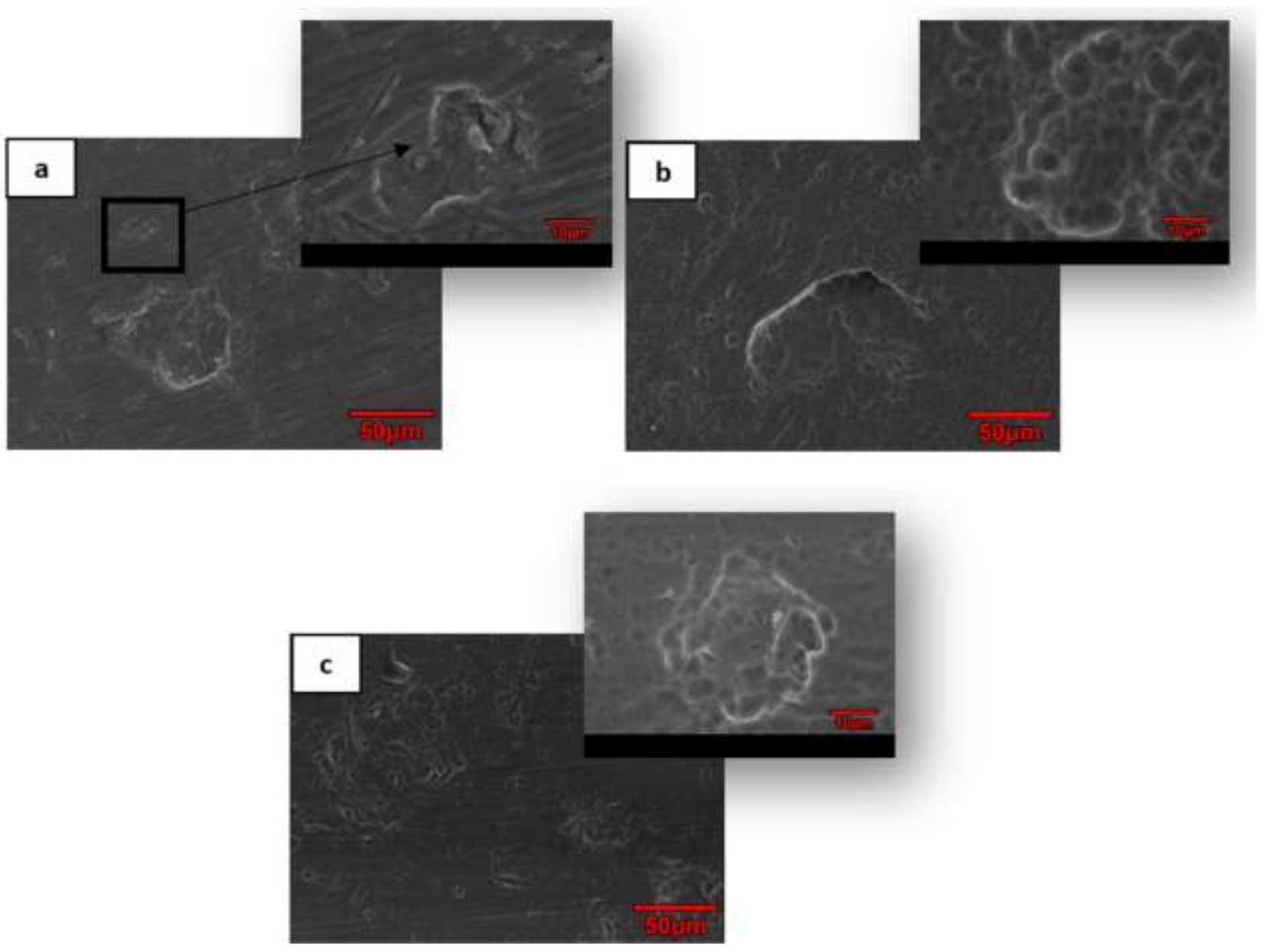

Source: Authors.

All samples showed in Figure 14 exhibit regular morphology and is not possible to identify the formation of corrosion products. Despite this observation, impedance tests (Figure 12) pointed to a worse anti-corrosion performance in inflammatory SBF. This behavior under inflammatory conditions can be attributed to high rates of half-cell cathodic and anodic reactions. A change in the $\mathrm{pH}$ of the inflammatory electrolyte to 5 , combined with the consumption of a large amount of the $\mathrm{H}_{2} \mathrm{O}_{2}$ in solution suggests high rates of cathodic reactions. Enhanced rates of anodic reactions are evidenced by the high levels of ion release measured for inflammatory conditions when compared to normal conditions (E. K. Brooks et al., 2017).

After implantation of an orthopedic device, an inflammatory reaction is initiated both in response to the invasion due to the procedure and by the presence of the biomaterial device. This reactions cam generates reactive oxygen species by cells just because to the inflammatory response (Anderson, Rodriguez, \& Chang, 2008). In this process enzymes quickly consume and catalyzes the conversion to hydrogen peroxide $\left(\mathrm{H}_{2} \mathrm{O}_{2}\right)$ (Babior, Kipnes, \& Curnutte, 1973). In addition to the local increase in the concentration of $\mathrm{H}_{2} \mathrm{O}_{2}$, cells also produce lactic acid increasing $\mathrm{pH}$ around the implant. Some previous works had shown that an inflammatory simulations were capable of affecting the electrochemical properties of titanium and its alloys (Fonseca \& Barbosa, 2001; E. Brooks et al., 2014). 


\section{Conclusion}

The anodizations made in titanium using different electrolytes ( 1 mol L-1 H3PO4 and 1 mol L-1 H3PO4 + 0.15\% HF) showed similar behavior observed in the anodizing transients. The initial peak of the current and the low applied potential resulted in the formation of thin oxide. Despite this, the oxides formed are of the barrier and porous type. From the morphological conclusions it was verified that the sample anodized in 1 mol L-1 H3PO4 $+0.15 \%$ HF there was the formation of crystalline structures, but with the oxide rupture, only superficially, indicating the oxygen evolution in the layer. This justifies the results obtained in anodizing transients.

The barrier sample showed the best hydrophobicity results in both electrolytes (healthy and inflammatory SBF) which is desired as it improves the interaction with biological fluids. Furthermore, a better anticorrosive performance was observed for this sample in the electrochemical characterization, mainly in inflammatory SBF, thus ensuring a longer life for the implant.

Regarding the results obtained, it is concluded that the barrier sample was the one that presented the best performance, mainly considering the behavior in inflammatory fluid.

\section{Acknowledgments}

The present work was carried out with support of CAPES, Brazilian Government entity focused in human resources formation. The authors also thank to the financial support of Brazilian agencies: CNPq, FAPERGS and National Institute of Surface Engineering - INCT.

\section{References}

Albuquerque, A. R., Santos, I. M. G., \& Sambrano, J. R. (2014). Structural And Electronic Properties Of Anatase Tio 2 Thin Films: Periodic B3lyp-D* Calculations In 2d Systems. Química Nova, 37(8), 1318-1323. http://www.gnresearch.org/doi/10.5935/0100-4042.20140187

Almeida, P. C., \& Reis, A. G. (2018). O titânio e suas ligas na implantodontia atual e sua caracterização diante das opções de tratamento de superfície Titanium and its alloys in the current implantology and its characterization in front. ClipeOdonto, 9(1), 66-72.

Ammar, S., Ramesh, K., Vengadaesvaran, B., Ramesh, S., \& Arof, A. K. (2016). Amelioration of anticorrosion and hydrophobic properties of epoxy/PDMS composite coatings containing nano ZnO particles. Progress in Organic Coatings, 92, 54-65. https://linkinghub.elsevier.com/retrieve/pii/S0300944015303751

Anderson, J. M., Rodriguez, A., \& Chang, D. T. (2008). Foreign body reaction to biomaterials. Seminars in Immunology, 20(2), 86-100. https://linkinghub.elsevier.com/retrieve/pii/S1044532307000966

Araújo, T. De, \& Couto, A. (2004). Estudo do aço inoxidável aplicado como implante ortopédico. Revista Mackenzie, 20. http://www.mackenzie.br/fileadmin/Graduacao/EE/Revista_on_line/aco_inoxidavel.pdf

Babior, B. M., Kipnes, R. S., \& Curnutte, J. T. (1973). Biological Defense Mechanisms. The Production by Leukocytes of Superoxide, a Potential Bactericidal Agent. Journal of Clinical Investigation, 52(3), 741-744. http://www.jci.org/articles/view/107236

Bohner, M., \& Lemaitre, J. (2009). Can bioactivity be tested in vitro with SBF solution? Biomaterials, 30(12), 2175-2179. https://linkinghub.elsevier.com/retrieve/pii/S0142961209000167

Bojinov, M., Betova, I., \& Karastoyanov, V. (2020). Modeling barrier film growth and dissolution on titanium based on EIS, XPS and photocurrent data. Electrochimica Acta, 344, 136137. https://linkinghub.elsevier.com/retrieve/pii/S0013468620305296

Brånemark, P.-I., Breine, U., Adell, R., Hansson, B. O., Lindström, J., \& Ohlsson, Å. (1969). Intra-Osseous Anchorage of Dental Prostheses: I. Experimental Studies. Scandinavian Journal of Plastic and Reconstructive Surgery, 3(2), 81-100. http://www.tandfonline.com/doi/full/10.3109/02844316909036699

Brooks, E. K., Brooks, R. P., \& Ehrensberger, M. T. (2017). Effects of simulated inflammation on the corrosion of $316 \mathrm{~L}$ stainless steel. Materials Science and Engineering: $C$, 71, 200-205. https://linkinghub.elsevier.com/retrieve/pii/S0928493116316587

Brooks, E., Tobias, M., Krautsak, K., \& Ehrensberger, M. (2014). The influence of cathodic polarization and simulated inflammation on titanium electrochemistry. Journal of Biomedical Materials Research - Part B Applied Biomaterials.

Bruno Serafim Parra, Ronaldo Crosio Gennari, F. G. M., \& Boschi, A. O. (2006). Rugosidade Superficial de Revestimentos Cerâmicos. Cerâmica Industrial, 11(2), 16-18.

C.J.Dell'Oca, D.L.Pulfrey, \& L.Young. (1971). Anodic Oxide Films. Physics of Thin Films, 6, 1-79. 
Cao, Z., Kong, G., Che, C., \& Wang, Y. (2017). Influence of Nd addition on the corrosion behavior of $\mathrm{Zn}-5 \% \mathrm{Al}$ alloy in $3.5 \mathrm{wt}$.\% NaCl solution. Applied Surface Science, 426, 67-76. https://linkinghub.elsevier.com/retrieve/pii/S0169433217321001

Casagrande, R. B., Kunst, S. R., Beltrami, L. V. R., Aguzzoli, C., Brandalise, R. N., \& de Fraga Malfatti, C. (2018). Pretreatment effect of the pure titanium surface on hybrid coating adhesion based on tetraethoxysilane and methyltriethoxysilane. Journal of Coatings Technology Research, 1-18.

Catauro, M., Bollino, F., Papale, F., Giovanardi, R., \& Veronesi, P. (2014). Corrosion behavior and mechanical properties of bioactive sol-gel coatings on titanium implants. Materials Science and Engineering C, 43, 375-382. Elsevier B.V.

Chen, Q., \& Thouas, G. A. (2015). Metallic implant biomaterials. Materials Science and Engineering R: Reports, 87, 1-57. Elsevier B.V.

Costa, L. J., Sousa, E. T. De, Lucena, F. L. De, Cecilia, R., \& Souza, V. De. (2015). Surface of Titanium Implants and your Ability to Stimulate Bone Formation: A Review of Literature. Odontol. Clín.-Cient., 14(4), 797-800.

Cremasco, A., Andrade, P. N., Contieri, R. J., Lopes, E. S. N., Afonso, C. R. M., \& Caram, R. (2011). Correlations between aging heat treatment, $\omega$ phase precipitation and mechanical properties of a cast Ti-Nb alloy. Materials \& Design, 32(4), 2387-2390. https://linkinghub.elsevier.com/retrieve/pii/S0261306910006382

Dalmau, A., Guiñón Pina, V., Devesa, F., Amigó, V., \& Igual Muñoz, A. (2013). Influence of fabrication process on electrochemical and surface properties of Ti-6Al-4V alloy for medical applications. Electrochimica Acta, 95, 102-111. https://linkinghub.elsevier.com/retrieve/pii/S0013468613002028

Dubruel, P., Vanderleyden, E., Bergadà, M., De Paepe, I., Chen, H., Kuypers, S., Luyten, J., et al. (2006). Comparative study of silanisation reactions for the biofunctionalisation of Ti-surfaces. Surface Science, 600(12), 2562-2571. https://linkinghub.elsevier.com/retrieve/pii/S0039602806005073

Fadl-allah, S. A., \& Mohsen, Q. (2010). Applied Surface Science Characterization of native and anodic oxide films formed on commercial pure titanium using electrochemical properties and morphology techniques. Applied Surface Science, 256(20), 5849-5855. Elsevier B.V. http://dx.doi.org/10.1016/j.apsusc.2010.03.058

Fonseca, C., \& Barbosa, M. . (2001). Corrosion behaviour of titanium in biofluids containing H2O2 studied by electrochemical impedance spectroscopy. Corrosion Science, 43(3), 547-559. https://linkinghub.elsevier.com/retrieve/pii/S0010938X00001074

Goriainov, V., Cook, R., M. Latham, J., G. Dunlop, D., \& Oreffo, R. O. C. (2014). Bone and metal: An orthopaedic perspective on osseointegration of metals. Acta Biomaterialia, 10(10), 4043-4057. https://linkinghub.elsevier.com/retrieve/pii/S1742706114002517

Le Guéhennec, L., Soueidan, A., Layrolle, P., \& Amouriq, Y. (2007). Surface treatments of titanium dental implants for rapid osseointegration. Dental Materials, 23(7), 844-854. https://linkinghub.elsevier.com/retrieve/pii/S0109564106001850

Guilherme, A. S., Henriques, G. E. P., Zavanelli, R. A., \& Mesquita, M. F. (2005). Surface roughness and fatigue performance of commercially pure titanium and Ti-6Al-4V alloy after different polishing protocols. The Joournal of Prosthetic Dentistry, 93(4), 378-385.

Kang, S. M., Kong, B., Oh, E., Choi, J. S., \& Choi, I. S. (2010). Osteoconductive conjugation of bone morphogenetic protein-2 onto titanium/titanium oxide surfaces coated with non-biofouling poly(poly(ethylene glycol) methacrylate). Colloids and Surfaces B: Biointerfaces, 75(1), 385-389.

Kasemo, B., \& Lausmaa, J. (1985). Aspects of surface physics on titanium implants. Swedish dental journal. Supplement, 28, 19-36. https://www.ncbi.nlm.nih.gov/pubmed/3904061

Kokubo, T., Kushitani, H., Sakka, S., Kitsugi, T., \& Yamamuro, T. (1990). Solutions able to reproducein vivo surface-structure changes in bioactive glassceramic A-W3. Journal of Biomedical Materials Research, 24(6), 721-734. http://doi.wiley.com/10.1002/jbm.820240607

Kokubo, Tadashi, \& Takadama, H. (2006). How useful is SBF in predicting in vivo bone bioactivity? Biomaterials, 27(15), 2907-2915.

Kowalski, D., Kim, D., \& Schmuki, P. (2013). TiO2 nanotubes, nanochannels and mesosponge: Self-organized formation and applications. Nano Today, 8(3), 235-264. Elsevier Ltd. http://dx.doi.org/10.1016/j.nantod.2013.04.010

Kruger, J. (1979). Fundamental Aspects of the Corrosion of Metallic Implants. Corrosion and Degradation of Implant Materials (pp. 107-107-21). 100 Barr Harbor Drive, PO Box C700, West Conshohocken, PA 19428-2959: ASTM International. http://www.astm.org/doiLink.cgi?STP35940S

Kunst, S.R., Cardoso, H. R. P., Oliveira, C. T., Santana, J. A., Sarmento, V. H. V., Muller, I. L., \& Malfatti, C. F. (2014). Corrosion resistance of siloxanepoly(methyl methacrylate) hybrid films modified with acetic acid on tin plate substrates: Influence of tetraethoxysilane addition. Applied Surface Science, 298, 1-11. https://linkinghub.elsevier.com/retrieve/pii/S0169433213021089

Kunst, Sandra Raquel, Graef, T. F., Mueller, L. T., Morisso, F. D. P., Carone, C. L. P., Fuhr, L. T., Oliveira, C. T., et al. (2020). Superficial treatment by anodization in order to obtain titanium oxide nanotubes applicable in implantology. Matéria (Rio de Janeiro), 25(4). http://www.scielo.br/scielo.php?script=sci_arttext\&pid=S1517-70762020000400331\&tlng=em

Liu, Z., Liu, H., Zhong, X., Hashimoto, T., Thompson, G. E., \& Skeldon, P. (2014). Surface \& Coatings Technology Characterization of anodic oxide growth on commercially pure titanium in NaTESi electrolyte. Surface \& Coatings Technology, 258, 1025-1031. Elsevier B.V. http://dx.doi.org/10.1016/j.surfcoat.2014.07.036

Lütjering, G., \& Williams, J. C. (2007). Titanium. Engineering Materials, Processes (2nd ed.). Berlin, Heidelberg: Springer Berlin Heidelberg. http://link.springer.com/10.1007/978-3-540-73036-1

Marino, C. E. B., \& Mascaro, L. H. (2011). Electrochemical Tests to Evaluate the Stability of the Anodic Films on Dental Implants. International Journal of Electrochemistry, 2011, 1-7. 
Marino, C. E. B., de Oliviera, E. M., Rocha-Filho, R. C., \& Biaggio, S. R. (2001). On the stability of thin-anodic-oxide films of titanium in acid phosphoric media. Corrosion Science, 43(8), 1465-1476.

Oliveira, C. T. (2007). Caracterização microestrutural e Eletroquimica de óxidos de nióbio crescidos por anodização. Universidade Federal do Rio Grande do Sul Porto Alegre.

Park, J., Bauer, S., von der Mark, K., \& Schmuki, P. (2007). Nanosize and Vitality: TiO2 Nanotube Diameter Directs Cell Fate. Nano Letters, 7(6), 16861691. https://pubs.acs.org/doi/10.1021/n1070678d

Park, J. H., Olivares-Navarrete, R., Baier, R. E., Meyer, A. E., Tannenbaum, R., Boyan, B. D., \& Schwartz, Z. (2012). Effect of cleaning and sterilization on titanium implant surface properties and cellular response. Acta Biomaterialia, 8(5), 1966-1975. Acta Materialia Inc. http://dx.doi.org/10.1016/j.actbio.2011.11.026

Pentti, T., \& Lundstrom, I. (1992). ical Considerations of Tita. Clinical Materials, 9, 115-134.

Pfeiffer, F., Herzog, B., Kern, D., \& Scheideler, L. (2003). C ell reactions to microstructured implant surfaces. Microelectronic Engineering, 68, $913-922$.

Prządka, D., Marcinkowska, A., \& Andrzejewska, E. (2016). POSS-modified UV-curable coatings with improved scratch hardness and hydrophobicity. Progress in Organic Coatings, 100, 165-172. https://linkinghub.elsevier.com/retrieve/pii/S0300944016300467

Raja, K. S., Misra, M., \& Paramguru, K. (2005). Formation of self-ordered nano-tubular structure of anodic oxide layer on titanium. Electrochimica Acta, 51, $154-165$.

Ramires, I., \& Guastaldi, A. C. (2002). Estudo do biomaterial Ti-6Al-4V empregando-se técnicas eletroquímicas e XPS. Química Nova, 25(1), 10-14.

Ribeiro Filho, S. L. M., Lauro, C. H., Bueno, A. H. S., \& Brandão, L. C. (2016). Influence cutting parameters on the surface quality and corrosion behavior of Ti-6Al-4V alloy in synthetic body environment (SBF) using Response Surface Method. Measurement: Journal of the International Measurement Confederation, 88, 223-237.

Salvador, D. G., Marcolin, P., Beltrami, L. V. R., Brandalise, R. N., \& Kunst, S. R. (2017). Influence of the pretreatment and curing of alkoxysilanes on the protection of the titanium-aluminum-vanadium alloy. Journal of Applied Polymer Science, 134(46), 45470. http://doi.wiley.com/10.1002/app.45470

Salvador, D. G., Marcolin, P., Beltrami, L. V. R., Brandalise, R. N., \& Kunst, S. R. (2018). Development of Alkoxide Precursors-Based Hybrid Coatings on Ti-6Al-4V Alloy for Biomedical Applications : Influence of pH of Sol. Journal of Materials Engineering and Performance, 27(Ref 7), 2863-2874. Springer US.

Santana, J. A., Kunst, S. R., Oliveira, C. T., Bastos, A. A., Ferreira, M. G. S., \& Sarmento, V. H. V. (2020). PMMA-SiO2 organic-inorganic hybrid coating application to Ti-6Al-4V alloy prepared through the sol-gel method. Journal of the Brazilian Chemical Society, 31(2), 409-420.

Science, C., Britain, G., Science, M., \& Ng, N. (1988). Department of Metallurgy and Materials Science, The University of Nottingham, University Park, Nottingham NG7 2RD, U.K. Corrosion Science, 28(1), 43-56.

Shibata, Y., \& Tanimoto, Y. (2015). A review of improved fixation methods for dental implants. Part I: Surface optimization for rapid osseointegration. Journal of Prosthodontic Research, 59(1), 20-33. https://linkinghub.elsevier.com/retrieve/pii/S1883195814001194

Simons, W., Hubin, A., \& Vereecken, J. (1999). The role of electrochemical impedance spectroscopy (EIS) in the global characterisation of the reduction kinetics of hexacyanoferrate on anodised titanium. Electrochimica Acta, 44(24), 4373-4381. https://linkinghub.elsevier.com/retrieve/pii/S001346869900153X

Souza, J. C. M., Barbosa, S. L., Ariza, E. A., Henriques, M., Teughels, W., Ponthiaux, P., Celis, J.-P., et al. (2015). How do titanium and Ti6Al4V corrode in fluoridated medium as found in the oral cavity? An in vitro study. Materials Science and Engineering: C, 47, 384-393. Elsevier B.V. https://linkinghub.elsevier.com/retrieve/pii/S0928493114007565

Variola, F., Brunski, J. B., Orsini, G., Tambasco de Oliveira, P., Wazen, R., \& Nanci, A. (2011). Nanoscale surface modifications of medically relevant metals: state-of-the art and perspectives. Nanoscale, 3(2), 335-353. http://xlink.rsc.org/?DOI=C0NR00485E

Vermesse, E., Mabru, C., \& Arurault, L. (2013). Applied Surface Science Surface integrity after pickling and anodization of Ti $-6 \mathrm{Al}-4 \mathrm{~V}$ titanium alloy. Applied Surface Science, 285, 629-637. Elsevier B.V. http://dx.doi.org/10.1016/j.apsusc.2013.08.103

Vogler, E. A. (1998). Structure and reactivity of water at biomaterial surfaces. Advances in Colloid and Interface Science, 74(1-3), 69-117. https://linkinghub.elsevier.com/retrieve/pii/S0001868697000407

Wen, C. (2015). Surface Coating and Modification of Metallic Biomaterials. Surface Coating and Modification of Metallic Biomaterials, 1(c), 1-431.

Wieland, M., Chehroudi, B., Textor, M., \& Brunette, D. M. (2002). Use of Ti-coated replicas to investigate the effects on fibroblast shape of surfaces with varying roughness and constant chemical composition. Journal of Biomedical Materials Research, 60, 434-444.

Xing, J., Xia, Z., Hu, J., Zhang, Y., \& Zhong, L. (2013). Time dependence of growth and crystallization of anodic titanium oxide films in potentiostatic mode. CORROSION SCIENCE, 75, 212-219. Elsevier Ltd. http://dx.doi.org/10.1016/j.corsci.2013.06.004

Yan, Y., Chibowski, E., \& Szcześ, A. (2017). Surface properties of Ti-6Al-4V alloy part I: Surface roughness and apparent surface free energy. Materials Science and Engineering C, 70, 207-215.

Zhang, Z., Ge, B., Men, X., \& Li, Y. (2016). Mechanically durable, superhydrophobic coatings prepared by dual-layer method for anti-corrosion and selfcleaning. Colloids and Surfaces A: Physicochemical and Engineering Aspects, 490, 182-188.

Zhou, C., Xu, S., Pi, P., Cheng, J., Wang, L., Yang, J., \& Wen, X. (2018). Polyacrylate/silica nanoparticles hybrid emulsion coating with high silica content for high hardness and dry-wear-resistant. Progress in Organic Coatings, 121(April), 30-37. Elsevier. 